\title{
COMMENTS
}

\section{PROCEDURAL PROTECTION AT PAROLE RELEASE HEARINGS: THE NEED FOR REFORM}

In the past decade, both state and federal courts have greatly expanded the scope of the constitutional protections to which prisoners are entitled. Armed with the principle that inmates' constitutional rights cannot lawfully be diluted beyond the extent necessary for orderly prison administration, ${ }^{1}$ the courts have placed strict substantive limitations upon the degree to which authorities may control prisoners' activities. $^{2}$ In addition, prison officials must now observe specific procedural safeguards in a wide variety of contexts whereas their actions have previously been free from such judicially imposed restraints. ${ }^{3} \mathrm{~Pa}-$ role release decisions are virtually the only crucial area in the correctional process where the effects of this judicial revolution are still subject to serious doubt. ${ }^{4}$ The main reason for this exception is that in parole

\footnotetext{
THE FOLLOWING CITATIONS WILL BE USED IN THIS COMMENT:

K. Davis, AdminIStrative LAW TEXT (1972) [hereinafter cited as K. Davis];

National Advisorx Comm'n on Criminal Justice Standards and Goals, CorRECTIONS (1973) [hereinafter cited as NATIONAI ADVISORY COMM'N];

PRESIDENT'S COMM'N ON LAW ENFORCEMENT AND ADMINISTRATION OF JUSTICE, TASR FORCE REPORT: CORRECTIONS (1967) [hereinafter cited as TASR FORCE REPORT];

Parsons-Lewis, Due Process in Parole-Release Decisions, 60 CALIF. L. REv. 1519 (1972) [hereinafter cited as Parsons-Lewis];

Comment, Entitlement, Enjoyment, and Due Process of Law, 1974 DUKe L.J. 89 [hereinafter cited as Entitlement, Enjoyment, and Due Process];

Comment The Parole System, 120 U. PA. L. REv. 282 (1971) [hereinafter cited as The Parole System].

1. See Wolff v. McDonnell, 94 S. Ct. 2963, 2974-75 (1974).

2. Prisoners have successfully challenged the actions of government officials on a wide variety of substantive grounds, including the first amendment's protection of speech and religious freedom, the eighth amendment's proscription of cruel and unusual punishment, the due process clause of the fifth amendment, and the due process and equal protection clauses of the fourteenth amendment. See notes 40-47 infra and accompanying text.

3. See notes 48-50 infra and accompanying text. The current judicial attitude is exemplified by the District Court for the Northern District of New York: "No longer can prisons and their inmates be considered a closed society with every internal disciplinary judgment to be blissfully regarded as immune from the limelight that all public agencies are ordinarily subject to ." Wright v. McMann, 321 F. Supp. 127, 132 (N.D. N.Y. 1970).

4. Three recent circuit court decisions have extended due process protection to parole release hearings. See Bradford v. Weinstein, No. 73-1751 (4th Cir. Nov. 22, 1974);
} 
release proceedings no interest is affected that satisfies a strict interpretation of the requirements which the Supreme Court has recognized as necessary in order for due process protection to be invoked. ${ }^{5}$

This Comment will examine the practical and legal aspects of the need for procedural protection at parole release hearings. A discussion of the perfunctory and arbitrary methods in general use today will first be presented. By way of contrast, the next section will show the dramatic recent increase in judicial intervention which has affected almost every other area of prison life. An outline will then be given of the "present enjoyment" and "entitlement" doctrines which currently restrict the interests which are protected by the due process clauses of the fifth and fourteenth amendments. It will be shown that parole release decisions are unlike other important determinations of prisoners' rights in that they fail to qualify for protection under a rigid apphication of either doctrine, except in very limited circumstances. The concluding section will offer a proposal for legislative action which is needed to establish fairness and consistency in the parole system.

\section{The Current System: Parole Release Decisions by STatute AND IN Practice ${ }^{6}$}

Almost every inmate of a correctional institution faces a parole board at least once durimg his prison term. ${ }^{7}$ The board decides whether the inmate will spend the balance of his sentence within the correctional institution. If parole is refused, the board often determines when the inmate's request for parole may next be considered. In effect, parole boards establish the length of a prisoner's period of incarceration within certain judicial or statutory minima and maxima. The

United States ex rel. Johnson v. Chairman of N.Y. State Bd. of Parole, 500 F.2d 925 (2d Cir.), vacated as moot sub nom. Reagan v. Johnson, 43 U.S.L.W. 3294 (U.S. Nov. 19, 1974) (No. 74-108); Childs v. United States, No. 74-1052 (D.C. Cir. Dec. 19, 1974). None of these conrts, however, adeqnately explained its refusal to apply a strict version of the due process qualifying tests approved by the Supreme Court. See notes 101-23 infra and accompanying text.

5. For an outline of these tests, see notes 53-86 infra and accompanying text. A more extensive discussion and criticism of these doctrines can be found in Entitlement, Enjoyment, and Due Process. The possibility that "liberty" interests (the category into which a prospective parolee's interest in his freedom would fall) might be exempted from the strict "present enjoyment" standards of the due process tests is discussed at notes 80-81 \& 113-21 infra and accompanying text.

6. See generally The Parole System 300-07. . .

7. Certain inmates, such as those serving life sentences, are sometimes considered ineligible for parole. See IOWA CODE ANN. § 247.5 (1969). However of the 83,000 felons who left correctional institutions in 1970, seventy-two percent were released on parole, See NATIONAL ADVISORY COMM'N'389: 
importance of this determination both for the inmate and for society imght seem to make such proceedings an obvious area for legislative attention. However, few existing statutes reflect any trend toward establishing regular procedures and specific standards in parole release hearings. ${ }^{8}$ Most parole boards, including the federal parole boards, are given the statutory authority to determine when an inmate who is eligible for parole may be released, but are given little statutory instruction as to how that determination should be made. ${ }^{9}$ Typically, legislatures provide the parole boards with only minimal criteria as to which prisoners should be paroled, and these criteria are generally so vague as to give parole boards hittle guidance in making their determinations. ${ }^{10}$ For example, most statutes provide simply that a parole board has the authority to grant parole when in its opinion there is reasonable probability that the prisoner can be released without detriment to the community or himself. ${ }^{11}$

Legislatures provide an equally minimal amount of guidance as to what procedures need be followed by parole boards. Only a few statutes require hearings, ${ }^{12}$ although in practice almost all parole boards

8. See The Parole System 292. But see Kan. Stat. ANN. \& 62-2245 (1964) (requiring a hearing and listing parole release criteria).

9. See 18 U.S.C. $\$ \$ 4203-09$ (1970). In section 4203 , the statute gives the parole board authority to use its discretion in releasing an eligible inmate on parole but does not define the procedures to be followed. See also Colo. Rev. Stat. Ann. § 39-18-1 (1963), which provides that the state parole board may use its discretion to grant applications for parole but lists no specific procedures for processing the applications. In applying this statute, one court has stated: "The Board is free to proceed in any manner that is not arbitrary." Johnson v. Heggie, 362 F. Supp. 851, 854 (D. Colo. 1973).

10. See Allen, Legal Values and Correctional Values, 18 U. ToRonto L.J. 119, 125 (1968); The Parole System 304.

11. See, e.g., Del. Code ANn. tit. 11, \& 4347(a) (Supp. 1970); Mo. Rev. Stat. § 549.261 (1969). Soine states make the additional requirement that, in the board's opinion, the inmate will not violate the law. See N.Y. Correction LAw $\$ 213$ (McKinney Supp. 1974). A few states do list additional factors which should be considered by parole boards. See MD. CoDE ANN. art. 41, \$111 (1957): herein

It shall be the duty of the Board in carrying out its powers authorized

(1) In determining whether a prisoner is suitable for relase on parole:

(I) To consider the circumstances surrounding the crime, and the physical, mental and moral qualifications of persons who become eligible for parole;

(II) To determine. whether there is reasonable probability that the prisoner, if released on parole, will remain at liberty without violating the laws, and whether the release of the prisoner on parole is compatible with the welfare of society;

…

(5) To arrange, in its discretion, psychiatric or psychological examinations of applicants for parole, when it feels such examination will better enable it to decide on the àdvisability of parole.

12. See, e.g., KAN. Stat. ANN. \$ 62-2245 (1964); MD. CoDE ANN, art. 41, § 112(b) (1957). 
provide hearings as a matter of course. ${ }^{13}$ Beyond this generally accepted procedure, however, parole boards differ as to whether they allow an inmate to present evidence, confront witnesses, be represented by counsel, or be provided with a written statement of reasons for denial of parole. ${ }^{14}$ None of these safeguards is observed by more than a minority of jurisdictions. ${ }^{15}$

The consequences of a lack of procedural safeguards can be seen in New York's rather typical parole release procedure. The New York State Parole Board is composed of not more than twelve niembers, ${ }^{16}$ although the Board works in three-member panels. ${ }^{17}$ All three members must agree to grant parole, and therefore a single dissenting member can deny parole. The Official Report by the Attica Commission graphically portrayed the superficial nature of these proceedings. The Commission observed that the average time taken by the panels in considering an inmate's case (reading the folder, interviewing the inmate, and making the determination) is 5.9 minutes. The Report stated:

The parole folder may have as many as 150 pages of reports on the inmate which he has never seen. Two of the Commissioners often read the files of the inmates next in line while an inmate is questioned by a third Commissioner. . . . The questions are often superficial: "Do you feel you have the capabilities of functioning on the outside as a cook?" If the questions delve more deeply, they often concentrate on the inmate's past crime, rather than on this [sic] present condition or plans for the future. No one who worked with the inmate in prison is heard by the board.

The panel reaches a decision immediately after the conclusion of the hearing. The two Coinmissioners who have been reading other in-

13. In all states except Georgia, Hawaii, and Texas, adult offenders are entitled to be present at the hearings in which their applications for parole are considered. The parole boards of four states screen the files of inmates eligible for parole, and only those cases which merit further consideration are set for hearings at which the prisoner is interviewed. See National Advisory COMM'N 400.

14. See Dawson, The Decision to Grant or Deny Parole: A Study of Parole Criteria in Law and Practice, 1966 WASH. U.L.Q. 243, 302; O'Leary \& Nuffield, Parole Decision-Making Characteristics: Report of a National Survey, 8 CRIM. L. BULL. 651, 658 (1973).

15. Of the fifty-one jurisdictions surveyed in a recent study, twenty-one allowed the presence of counsel at parole release proceedings, but there was no provision for the representation of indigents and in fact the participation of attorneys on behalf of inmates was extremely rare. See O'Leary \& Nuffield, $A$ National Survey of Parole Decision-making, 19 CRIME and DeLINQuency 378, 386 (1973). Seventeen jurisdictions allowed witnesses for the inmate to appear at the hearing. Id. Although many jurisdictions informed the inmate of the reasons for denial of his parole application, only eleven kept any written record of these reasons. $1 d$. at 387.

16. N.Y. CoRrection LAW \& 6(1) (McKinney Supp. 1974).

17. Id. $\S 214(5)$. 
mates' files generally acquiesce in the recommendation of the Commissioner who has read the file and questioned the mmate under consideration. The legal requirement that all three Commissioners participate in the decision is satisfied only in the most perfunetory way. ${ }^{18}$

If parole is denied, the panel sets a date within two years for the innuate's next interview. The decision is communicated to the prisoner on a form which gives no reasons for the denial and offers no suggestions as to how the inmate might improve his chances of being released when his case is next considered. ${ }^{19}$

\section{Arbitrariness Abounds}

The absence of judicially imposed procedural safeguards and the presence of nebulous statutory guidelines have resulted in sweeping discretionary powers for the parole boards. Accordingly, the possibility of arbitrariness in parole board determinations is very great. ${ }^{20}$ There are additional factors associated with the decision-making process itself which further decrease the likelihood of a thoroughly reasoned decision. First, there is the sheer volume of cases which a parole panel must review daily; with such a caseload the chances of careless factual mistakes and hastily drawn inferences are substantial. ${ }^{21}$ In addition, because most of the decision-1naking of correctional personnel is

18. United States ex rel. Johnson v. Chairman of N.Y. State Bd. of Parole, 500 F.2d 925, 931-32 (2d Cir.), vacated as moot sub nom. Regan v. Johnson, 43 U.S.L.W. 3294 (U.S. Nov. 19, 1974) (No. 74-108), quoting New York STATE Special COMM'N on AtTiCA, Offictal Report 96-97 (Bantam Books 1972). See also D. Dressler, Practice and Theory of Probation and Parole 116-17 (2d ed. 1969).

19. United States ex rel. Johnson v. Chairman of N.Y. State Bd. of Parole, 500 F.2d 925, 932 (2d Cir.), vacated as moot sub nom. Regan v. Johnson, 43 U.S.L.W. 3294 (U.S. Nov. 19, 1974) (No. 74-108), citing REPORT ON NEW York PAROLE BY Cittzens' Inquiry on Parole and Crminat Justice, Inc. 78-90 (1973); cf. Lupo v. Norton, 371 F. Supp. 156, 161 (D. Conn. 1974), where the conrt commended the Connecticnt Board of Parole's practice of making a table of guidelines and listing the reasons for denial of parole.

20. For example, it has been shown that a parole board systematically discriminated among conscientious objectors bascd upon their religious belief, favoring Jehovah's Witnesses. See Comment, Applying the Administrative Procedures Act to Federal Parole Decision Making in the Decision to Grant or Deny Parole, 8 HaRv. Civ. RIGHTS-CIV. LIB. L. REv. 419, 432-33 (1973).

21. The average number of applications considered by parole boards in a day varies from fifteen to sixty. See NATIONAL ADVISORY CoMm'N 400. In New York, parole panels will generally conduct forty to fifty interviews within a seven- or eighthour period. See United States exx rel. Johnson v. Chairman of N.Y. State Bd. of Parole, 500 F.2d 925, 932 (2d Cir.), vacated as moot sub nom. Regan v. Johnson, 43 U.S.L.W. 3294 (U.S. Nov. 19, 1974) (No. 74-108). See also In re Stnrm, 11 Cal. 3d 258, 270, 521 P.2d 97, 105, 113 Cal. Rptr. 361, 369 (1974): "[T]here is little inherent guard against careless decisions in the absence of a statement of reasons, especially in view of the Authority's [parole board's] treinendous case load." 
less visible to the public than the decision-making of other governmental agencies, it is "less likely to benefit from the inherent restraints of public discussion and scrutimy."22 There is also, in general, very little participation by prisoners in the decision-making process, thus removing another potential source of guidance for official discretion. ${ }^{23}$ Finally, because of the close contact between the inmates and the prison authorities who momitor and control almost every aspect of their lives, ${ }^{24}$ prison officials have a tremendous opportunity for abuse of power and discretion when they compile the reports upon which parole board nembers rely in making their decisions.

The arbitrariness which inevitably results is evidenced by notorious inconsistencies in parole board determinations; "[c]orruption and chance are anong the favorite inmate speculations." 25 The frustration experienced by inmates due to the current operations of parole boards is great. As the Second Circuit Court of Appeals has recently pointed out, "[o]ne can imagine nothing more cruel, inhuman and frustrating than serving a prison term without the knowledge of what will be measured and the rules determining whether one is ready for release."26 This frustration inpedes the inmates' prospects for rehabilitation and bears a direct relation to the maintenance of order in a correotional institution:

22. Palmigiano v. Baxter, 487 F.2d 1280, 1283 (1st Cir. 1973), vacated and remanded, 94 S. Ct. 3200 (1974) (speaking generally of decision-making by correctional officials).

23. See generally Note, Bargaining in Correctional Institutions: Restructuring the Relation Between the Inmate and the Prison Authority, 81 YALE L.J. 726 (1972).

24. See Palmigiano v. Baxter, 487 F.2d 1280, 1284 (1st Cir. 1973), vacated and remanded, 94 S. Ct. 3200 (1974).

25. United States ex rel. Johnson v. Chairman of N.Y. State Bd. of Parole, 500 F.2d 925, 932 (2d Cir.), vacated as moot sub nom. Regan v. Johnson, 43 U.S.L.W. 3294 (U.S. Nov. 19, 1974) (No. 74-108), quoting New York State Spectal Comm'N oN ATTICA, supra note 18, at 97 . The Johnson court further observed:

While the board acts favorably in most cases, it engenders hostility because of the inconsistency of its rationale. Some immates who have had good behavior records in prison are "hit" (denied parole), while others with many infractions are granted parole. Some inmates with a long record of prior offenses may receive parole, while others, including first offenders, may be denied it. Nobody gives the inmate an explanation for these obviously inconsistent decisions or describes in anything more than meaningless generalities the criteria used by the board in arriving at its decisions. Institutional parole officers give inmates pointers on what might snbsequently impress the board, such as enrolling in Bible classes. But inmates who follow this advice carefully often find they are hit nevertheless. As a result, immates are left to speculate among themselves as to the reasons for the board's decisions. Corruption and chance are among the favorite inmate speculations. 500 F.2d at 932 n.6, quoting New YORK STATE SPECIAL COMM'N ON ATTICA, supra note 18, at 97.

26. United States ex rel. Johnson v. Chairman of N.Y. State Bd. of Parole, 500 F.2d 925,933 (2d Cir.), vacated as moot sub nom. Regan v. Johnson, 43 U.S.L.W. 3294 (U.S. Nov. 19, 1974) (No. 74-108), citing K. Davis, DisCRETIONARY JusticE: A PRELIMINARY INQUIRY 132 (1969). 
[T]he orderly care with which decisions are made by the prison authority is intimately related to the level of respect with which prisoners regard that authority. There is nothing more corrosive to the fabric of a public institution such as a prison than a feeling among those whom it contains that they are being treated unfairly. ${ }^{27}$

These feelings on the part of inmates also frequently prejudice their attitudes toward public authority once they are released from prison, and the likelihood of further criminal conduct is thereby increased. ${ }^{29}$ Thus, the failure of the courts and the legislatures to impose upon parole boards procedural safeguards which would reduce the incidence of arbitrariness not only results in unfair treatment for the prisoners who are affected, but it also works directly against the interests of the state in the rehabilitation of its inmates and the maintenance of order within and outside correctional institutions. ${ }^{29}$

\section{General Expansion of Prisoners' Constitutional Rights}

The persistence of traditional methods in parole release hearings is in marked contrast to the sweeping changes which the courts have ordered in other aspects of prison life. This judicial activisin has discarded several hallowed theoretical justifications for the "hands off" policy which, until recently, was the universal attitude. Under the labels of "legislative grace," "custody," "parens patriae," and "privilege versus right," ${ }^{30}$ these theories had effectively precluded judicial intervention in the internal affairs of penal institutions. The result was that, absent a showing of exceptional circumstances, ${ }^{31}$ a prisoner could not enforce the rights enjoyed by free citizens. Accordingly, the courts generally refused even to examine the inerits of an inmate's complaint that he had been denied a constitutional right. ${ }^{32}$

27. Palmigiano v. Baxter, 487 F.2d 1280, 1283 (1st Cir. 1973), vacated and remanded, 94 S. Ct. 3200 (1974). Parole practices have often been blamed for much of the unrest in prisons. See generally Fox, Why Prisoners Riot, 35 Fed. Probation 9 (1971).

28. See TASK FoRCE REPORT 82.

29. See generally The Parole System 376.

30. For discussions of these older theories in the parole release context, see Note, Parole Status and the Privilege Concept, 1969 DUKE L.J. 139, 139-42; Note, Parole: A Critique of its Legal Foundations and Conditions, 38 N.Y.U.L. REv. 702, 704-20 (1963); The Parole System 286-89; cf. Note, Procedural Due Process in Peno-Correctional Administration: Progression and Regression, 45 ST. JoHN's L. REv. 468, 469-72 (1971).

31. See Note, Prisoners Rights Under Section 1983, 57 GEo. L.J. 1270, 1273-74 (1969), reprinted in 6 CRIM. I. BuLx. 237, 240-41 (1970). The most primitive form of the "hands off" doctrine viewed prisoners as having no rights because they were "slaves of the state." Ruffin v. Commonwealth, 62 Va. (21 Gratt.) 790, 796 (1871).

32. See Stroud v. Swope, 187 F.2d 850, 851 (9th Cir.), cert. denied, 342 U.S. 829 
By far the most important of the traditional justifications for judicial restraint was the theory that fifth or fourteenth amendment due process protected only those interests which could be characterized as "rights" rather than "privileges."33 The rationale for this distinction was that a benefit which the state was not required to grant in the first instance could be withdrawn or withheld in such a inanner as the granting state might direct. For example, when faced with a prisoner's claim to due process protection at a parole release hearing, a court would most commonly conclude that the prisoner had no vested right in being released prior to the expiration of his sentence; as parole was a mere privilege granted by the state, the courts lacked authority to interfere in parole release proceedings. ${ }^{34}$

These traditional justifications for the "hands off" policy have little, if any, vitality today. ${ }^{35}$ In reviewing prisoners' complaints, the courts have abandoned the doctrine that only those interests which can be viewed as "rights" are entitled to constitutional protection. The current judicial attitude was reiterated by the Supreme Court in the recent case of Wolff v. McDonnell. ${ }^{36}$ "Though his rights may be diminished by the needs and exigencies of the institutional environment, a prisoner is not wholly stripped of constitutional protections when he is imprisoned for crime. There is no iron curtain drawn between the

(1951) (dismissal of complaimt of inmate alleging interference with his right to secure publication of his book). See generally Note, Beyond the Ken of the Courts: $A$ Critique of Judicial Refusal to Review the Complaints of Convicts, 72 YALE L.J. 506 (1963).

33. By far the most frequently cited authority in support of this distinction was Justice (then Judge) Holmes' dismissal of a patrolman's argument that he could not be discharged for political activity: "The petitioner may have a constitutional right to talk politics, but he has no constitutional right to be a policeman." McAuliffe v. Mayor of New Bedford, 155 Mass. 216, 220, 29 N.E. 517, 517 (1892). See generally Van Alstyne, The Demise of the Right-Privilege Distinction in Constitutional Law, 81 HARV. L. Rev. 1439, 1439-42 (1968). The most frequent application of the rightprivilege doctrine was in the area of public employee dismissals. See Bailey v. Richardson, 182 F.2d 46, 59 (D.C. Cir. 1950), aff'd by an equally divided Court, 341 U.S. 918 (1951) (summary dismissal of federal employee upheld under theory that the Constitution does not "guarantee Government employ").

34. See Ex parte Smith, 33 Cal. 2d 797, 804, 205 P.2d 662, 666 (1949); cf. Escoe v. Zerbst, 295 U.S. 490 (1935).

35. The right-privilege distinction, which was the bulwark of the traditional approach, has been thoroughly discredited. See, e.g., Board of Regents of State Colleges v. Roth, 408 U.S. 564, 571 (1972); Graham v. Richardson, 403 U.S. 365, 374 (1971); Bell v. Burson, 402 U.S. 535, 539 (1971), Goldberg v. Kelly, 397 U.S. 254, 262 (1970); Shapiro v. Thompson, 394 U.S. 618, 627 n.6 (1969); Sherbert v. Verner, 374 U.S. 398, 404 (1963). See generally Van Alstyne, supra note 33.

36. 94 S. Ct. 2963 (1974) (imposing procedural requirements upon prison disciplinary hearings which might result in a loss of statutory "good time" credits). 
constitution and the prisons of this country."37 As a result, the courts have extended many constitutional protections behind prison walls.

Under the current judicial view whereby a "prisoner retains all the rights of an ordinary citizen except those expressly, or by necessary implication, taken from him by law,"38 the courts have been most generous in areas where "preferred" interests are affected. ${ }^{39}$ Accordingly, the specific safeguards of the Bill of Rights have been hiberally applied. For example, in 1964 the Supreme Court guaranteed an inmate his first amendment right to purchase religious publications, ${ }^{40}$ and in 1972 the Court granted similar protection to prisoners' freedom of worship. ${ }^{41}$ The interests of mail communication, visitation rights, receipt of hiterature, and prisoners' writings have also been given preferred treatinent as falling within the protections of the first amendment. ${ }^{42}$ Also, although the Supreme Court has never applied the eighth amendment to prison conditions or practices, lower courts have generally acknowledged that prisoners retain the right to be free from cruel and unusual punishment. ${ }^{43}$ Accordingly, one judge ruled that a bread and water diet which was intended to debilitate a prisoner was a violation of the eighth amendment. ${ }^{44}$ The same amendment has been applied to cases

37. Id. at 2974.

38. Coffin v. Reichard, 143 F.2d 443, 445 (6th Cir. 1944), cert. denied, 325 U.S. 887 (1945); cf. Price v. Johnston, 334 U.S. 266, 285 (1948), cited in Wolff v. McDonnell, 94 S. Ct. 2963, 2974 (1974): "Lawful incarceration brings about necessary withdrawal ... of many privileges and rights, a retraction justified by the considerations underlying our penal system." For a comparison of these two approaches, see Hollen, Emerging Prisoners' Rights, 33 OHo St. L.J. 1 (1972). Professor Hollen believes the Coffin view is now preferred by the courts. Id.

39. For an explanation of what coustitutes "preferred" interests, see notes 66-68 infra and accompanying text.

40. Cooper v. Pate, 378 U.S. 546 (1964).

41. Cruz v. Beto, 405 U.S. 319 (1972) (discrimination against prisoner denying him reasonable opportunity to practice the Buddhist faith).

42. See Bass, First Amendment Rights, in Prisoners' Rights Sourcebook 67 (M. Hernan \& M. Haft eds. 1973). Two recent cases have defined procedural safeguards which must be established to protect inmates' first amendnient rights. See Laaman v. Hancock, 351 F. Supp. 1265 (D.N.H. 1972); Sostre v. Otis, 330 F. Supp. 941 (S.D.N.Y. 1971).

43. See Turner, Challenging Conditions in Prisons Which Violate the Eighth Amendment, in PrISONERS' RIGHTS Sourcerook, supra note 42, at 113; Hollen, supra note 38 , at 43 (1972). However, the courts have experienced great difficulty in defining what constitutes cruel and unusual punishment. See Weems v. United States, 217 U.S. 349, 368 (1910); Novak v. Beto, 456 F.2d 1303, 1305 (5th Cir. 1972) (Wisdom, J., dissenting).

44. Landman v. Royster, 333 F. Supp. 621 (E.D. Va. 1971); see Sinclair v. Henderson 331 F. Supp. 804 (E.D. La. 1967) (denying regular outdoor exercise held violative of a death row inmate's eighth amendinent rights); cf. Ford v. Board of Managers, 407 F.2d 937 (3d Cir. 1969). 
involving a denial of nedical care to inmates when, for example, a serious and obvious injury or illness is dehberately overlooked, or an inmate with such an illness or injury is forced to perform other activities. ${ }^{45}$

Furthermore, the Suprenie Court has recognized that the guarantees of the fifth and fourteenth amendinents are applicable to prison life. Therefore, where possible racial discrimination is involved, prison officials will be held to a stringent standard in justifying the constitutionality of their practices under the equal protection clause. ${ }^{46}$ Certain substantive rights other than those expressly nentioned in the Bill of Rights have also been brought within the scope of the due process clauses. For example, the fourteenth amendment has been held to guarantee inmates' right of access to the courts. ${ }^{47}$ In addition, the procedural due process safeguards of the fifth and fourteenth amendinents, perhaps the constitutional proteotions most frequently invoked by prisoners, are receiving widespread application. In 1972, the Suprenie Court held that parolees facing parole revocation by correctional authorities were entitled to certain procedural protections, ${ }^{48}$ and the Court has recently decided that procedural due process requirements apply to a disciplinary hearing which may result in an inmate's loss of good time credits. ${ }^{49}$ Many lower courts have interpreted these decisions as requiring procedural protection whenever an inmate stands to suffer a serious change in his current prison status. ${ }^{50}$

45. Claims of inadequate medical care have been found to violate the eighth and fourteenth amendments where the conduct alleged "'shocks the conscience,' such as deliberate indifference by prison authorities to a prisoner's request for essential medical treatment." Williams v. Vincent, No. 73-2781 at 1110 (2d Cir. Dec. 30, 1974). See also Bishop v. Stoneman, No. 74-1326 (2d Cir. Dec. 4, 1974); Martinez v. Mancusi, 443 F.2d 921 (2d Cir. 1971) (prisoner required to walk despite surgeon's orders to the contrary); Redding v. Pate, 220 F. Supp. 124 (N.D. IIl. 1963) (prisoner had been given inadequate treatment for epileptic headaches); cf. Church v. Hegstrom, 416 F.2d 449 (2d Cir. 1969) (complaint alleging that jail officials ignored plaimtiff's illness did not state a cause of action under the federal civil rights statute absent serious injury).

46. See Jackson v. Godwin, 400 F.2d 529 (5th Cir. 1968) (upholding black inmates' right to receive black-oriented newspapers and magazines when white inmates were permitted to receive white-oriented literature); Washington v. Lee, $263 \mathrm{~F}$. Supp. 327, 331 (M.D. Ala. 1966), aff'd per curiam, 390 U.S. 333 (1968) (invalidating statute requiring prison segregation).

47. See Younger v. Gilmore, 404 U.S. 15 (1971), aff'g Gilmore v. Lynch, 319 F. Supp. 105 (N.D. Cal. 1970); Johnson v. Avery, 393 U.S. 483 (1969).

48. Morrissey v. Brewer, 408 U.S. 471 (1972).

49. Wolff v. McDonnell, 94 S. Ct. 2963 (1974).

50. See Palmigiano v. Baxter, 487 F.2d 1280, 1284 (1st Cir. 1973) vacated and remanded, 94 S. Ct. 3200 (1974) (due process safeguards required in disciphinary hearings). This is similar to the view of the dissenters in Wolff: "The Court apparently holds that inmates' 'liberty' is protected by due process whenever 'a major change in the conditions of confinement' is imposed as punishinent for misconduct." $94 \mathrm{~S}$. Ct. 
This dramatic expansion reflects a growing judicial awareness that the unjustified deprivation of prisoners' rights adversely affects the interests of the state in the orderly administration of its correctional institutions and the rehabilitation of inmates. ${ }^{51}$ The exceptions which have been made to the general trend are usually justified by the same considerations, as certaim restrictions which could not be imposed upon free citizens can reasonably be viewed as necessary for maintaining prison control. For example, the fourth amendinent freedoin from unauthorized searches and seizures would obviously harbor too many potential dangers to prison administration to be ineaningfully applied to a prisoner's cell. ${ }^{52}$

\section{Qualifying for Due Process Protection}

In the wake of the discredited right-privilege distinction, ${ }^{53}$ the Supreme Court spent several years searching for a new standard to use in deciding which interests are protected by the due process clauses of the fifth and fourteenth amendunents. A handful of transitional cases suggested that the new test would ultimately involve a judicial weighing of governmental and personal interests, with the balance shifting in favor of the individual whenever the potential hardship he might suffer seemed more substantial than the imconvemence which would be imposed upon the government by due process requirements. In Goldberg $v$. Kelly, ${ }^{54}$ wherein the Court held that certaim procedural safeguards must be observed prior to the termination of welfare benefits, ${ }^{55}$ the

at 2987 n.1 (Marshall, J., dissenting). See also Romero v. Schaver, 43 U.S.L.W. 2240, 2240 (D. Colo. Nov. 14, 1974) (The proposed transfer of a mental hospital patient to a penitentiary requires procedural due process protection, as such a transfer "may work 'a major change in the conditions of confinement' and thus affect liberty as protected by the Due Process Clause ....."); Gomes v. Travisono, No. 73-1066 (1st Cir. Dec. 20,1974 ) (reconsideration on remand) (interstate prison transfers).

51. See Clutchette v. Procunier, 497 F.2d 809, 817 (9th Cir. 1974). See also Hollen, supra note 38, at 4-5 (1972). A similar conclusion was reached in the report of the United States Task Force on Corrections, which states that

a first principle for any correctional institution is that staff control can be greatest, and certainly inmate life will be most relevant to that in the free community, if rules regulating behavior are as close as possible to those which would be essential for law and order in any free community, together with such minimal additional rules as are essential to meet the conditions peculiar to the institution. TASK FORCE REPORT 82.

52. See Lanza v. New York, 370 U.S. 139, 143-44 (1962) (prison is not a protected area such as the home). Contra, Burns v. Wilkinson, 333 F. Supp. 94 (W.D. Mo.' 1971).

53. See notes 33-35 supra and accompanying text.

54. 397 U.S. 254 (1970).

55. The safeguards included notice of the reasons for the termination of benefits, the right to confront opposing witnesses and to present oral arguments, as well as the right to retain counsel. Id. at 267-71. 
Court employed the following language: "The extent to which procedural due process must be afforded the recipient is influenced by the extent to which he may be 'condemned to suffer grievous loss' ... and depends upon whether the recipient's interest in avoiding that loss outweighs the governmental interest in summary adjudication."56 Several lower courts interpreted Goldberg (and other Supreme Court pronouncements with similar import ${ }^{57}$ ) as having estabhished a test of general apphication under which any due process claim would be resolved by a balancing of competing interests. 58 For instance, in adjudicating the case which was to become the Supreme Court's next major decision as to the scope of due process protection, the District Court for the Western District of Wisconsin, in Roth v. Board of Regents of State Colleges, ${ }^{59}$ carefully weighed the interest of a nontenured teacher in a pretermination hearing against the administrative interests which would be served by denying such a hearing. Primarily because of the personal hardships which the teacher might face as a result of his dismissal, ${ }^{B 0}$ the district court held that due process safeguards had to be observed. ${ }^{61}$ However, the Supreme Court reversed the district count's decision in Roth and specifically repudiated the weighing and balancing test apphed by the lower court. The Court stated: "[T]o determine whether due process requirements apply in

56. Id. at 262-63 (citation omitted). The Goldberg Court stressed the fact that cessation of financial assistance might deprive qualified recipients of "the very meaus by which to live" while the claimant's status was being determined by public officials. Id. at 264.

57. See, e.g., Cafeteria \& Restaurant Workers Local 473 v. McElroy, 367 U.S. 886, 895 (1961) (procedural protection in a given case depends upon "the precise nature of the government function involved as well as of the private interest that has been affected by governmental action"); Hannah v. Larche, 363 U.S. 420 , 442 (1960) (due process safeguards vary with the "nature of the alleged right involved, the nature of the proceeding, and the possible burden on that proceeding").

58. See, e.g., Palmigiano v. Baxter, 487 F.2d 1280, 1285 (1st Cir. 1973), vacated and remanded, 94 S. Ct. 3200 (1974); Miller v. Twomey, 479 F.2d 701, 713 (7th Cir. 1973), cert. denied, 414 U.S. 1146 (1974); Sostre v. McGinnis, 442 F.2d 178, 196 (2d Cir. 1971), cert. denied, 404 U.S. 1049 (1972). The Palmigiano decision is noteworthy for its two-step weighing aud balancing test under which the individual's interest is first weighed alone to determine the applicability of due process in the first instance, then balanced against the state's interest wheu the analysis shifts to the appropriateness of specific procedural safeguards. $487 \mathrm{~F} .2 \mathrm{~d}$ at 1284-85.

59. 310 F. Supp. 972 (W.D. Wis. 1970), rev'd, 408 U.S. 564 (1971).

60. Particular emphasis was given to the possibility that dismissal of a college teacher might adversely affect his professional career. $310 \mathrm{~F}$. Supp. at 979 . This and the possibility of injustice were considered to outweigh the university's interest in distinguishing between tenured and nontenured employees. Id.

61. The court felt that the appropriate safeguards were a statement of reasons "for non-retention, a hearing at which the teacher would be allowed to reply to the charges, and notice of this hearing. Id. at 980 . 
the first place, we must look not to the 'weight but to the nature of the interest at stake. We must look to see if the interest is within the Fourteenth Amendment's protection of liberty and property." ${ }^{2}$ The Roth Court restricted the balancing analysis exemplified by Goldberg to the determination of what procedural safeguards should be imposed after the claimant's interest is found to be of a type entitled to due process protection. ${ }^{63}$ The majority firmly rejected the lower court's assumption that the balancing test was the appropriate test for imitially establishing whether constitutional due process attaches at all. ${ }^{64}$

Two years after the Supreme Court's decision in Roth, the broad outlines of the new due process qualifying test are reasonably clear. ${ }^{85}$ There are certain interests whicl automatically fall within the due process clauses' "protection of liberty and property." This class includes those rights, such as freedom of speech, which are expressly included in the Bill of Rights. All of these rights apply to the federal government and many of them inay be asserted against the states by virtue of being "incorporated" into the fourteenth amendment. ${ }^{68}$ Also included are other rights, such as the right to privacy, which are regarded as implicit in the Bill of Rights and can likewise be enforced against the states under the imcorporation doctrine. ${ }^{67}$ A similar analy-

62. Board of Regents of State Colleges v. Roth, 408 U.S. 564, 570-71 (1972) (citation omitted) (emphasis in original). See also Wolff v. McDonnell, $94 \mathrm{~S}$. Ct. 2963, 2975 (1974); Arnett v. Kennedy, 94 S. Ct. 1633, 1643 (1974); Perry v. Sindermann, 408 U.S. 593, 599 (1972); Morrissey v. Brewer, 408 U.S. 471, 481 (1972); Fuentes v. Shevin, 407 U.S. 67, 84 (1972). The Supreme Court in Roth expressly characterized the district court's approach as a weighing and balancing test: "The District Court decided that procedural due process guarantees apply in this case by assessing and balancing the weight of the particular interests involved." 408 U.S. at 570.

63. "[A] weighing process has long been a part of any determination of the form of hearing required in particular situations by procedural due process." 408 U.S. at 570 (footuote omitted) (emphasis in original).

64. Id. at 570-71. The district court had felt constrained to apply a balancing test because of the language in Cafeteria \& Restaurant Workers Local 473 v. McElroy, 367 U.S. 886, 895 (1960), to the effect that a due process analysis involved "the precise nature of the government function involved as well as of the private interest that has been affected by governmental action." See notes 54-58 supra and accompanying text.

65. See generally Entitlement, Enjoyment, and Due Process.

66. See Dnncan v. Louisiana, 391 U.S. 145 (1968) (sixth amendment light to trial by jury in criminal cases).

67. See Roe v. Wade, 410 U.S. 113 (1973); Griswold v. Connecticut, 381 U.S. 479 (1965). Although the specific reasoning of Griswold, which characterized the right to privacy as deriving not from any specific constitutional provision but rather from the "penumbras" formed by "emanations" from specific provisions, id. at 484 , has not been used to create any further constitutional rights, the possibility of snch a further development is not foreclosed by any language in Griswold or its successors. Future rights which might be generated by this approach would presumably be of equal 
sis applies to those rights whicl are regarded as sufficiently "fundamental" to be implicit in the due process clauses of the fifth and fourteenth amendments. ${ }^{08}$ However, if the individual's interest cannot be placed within this class, the new liberty-or-property test imposes strict standards. In general, to qualify for protection such an interest inust be one to which the litigant is entitled, and, at least as regards property interests, only those interests whicl1 are presently enjoyed can be "deprived" so as to come within the protection of the due process clauses.

\section{The Entitlement Doctrine}

This branch of the new test was first enunciated by the Supreme Court in Roth, where the Court differentiated between those property interests that an individual wants or needs, and those to which he is entitled:

To have a property interest in a benefit, a person clearly must have more than an abstract need or desire for it. He must have more than a unilateral expectation of it. He must, instead, have a legitimate claim of entitlement to it. . . .

Property interests, of course, are not created by the Constitution. Rather they are created and their dimensions are defined by existing rules or understandings that stem from an independent source such as state law-rules or understandings that secure certain benefits and that support claims of entitlement to those benefits. ${ }^{00}$

Accordingly, the Roth court required the plaintiff teacher to show that a right to continued einployinent had been conferred upon him by his state's statutes or common law decisions. ${ }^{70}$ Only then could he present

stature with the Griswold-Roe privacy right and would thus be automatically incorporated into the fourteenth amendment.

68. A famous case employing this analysis is Rochin v. California, 342 U.S. 165 (1952), in which state law enforcement officers had assaulted the petitioner in an attempt to extract morphine capsules which he had swallowed. Having failed to obtain the capsules in this manner, the officers removed petitioner to a hospital, where the capsules were recovered by means of a forcibly administered emetic. Although no specific provision of the Bill of Rights was found to apply, the Court held that this "conduct that shocks the conscience," $i d$. at 172, violated the due process clause of the fourteenth amendment. The Court relied upon two famous opinions by Justice Cardozo as to the nature of the rights protected by substantive due process: Palko v. Connecticut, 302 U.S. 319, 325 (1937) (due process protects those values "implicit in the concept of ordered liberty"); Snyder v. Massachusetts, 291 U.S. 97, 105 (1934) (due process guarantees those interests which are "so rooted in the traditions and conscience of our people to be ranked as fundamental"). 342 U.S. at 169.

69. 408 U.S. at 577. See also Perry v. Sindermann, 408 U.S. 593, 603 (1972) (Burger, J. concurring); Clutchette v. Procunier, 497 F.2d 809, 815 (9th Cir. 1974).

70. 408 U.S. at 577-78. In Perry v. Sindermann, 408 U.S. 593 (1972), a companion case to Roth, the Court held that a teacher who could show an implied tenure 
a "property" interest to satisfy the threshold requirement posed by the due process qualifying test. Since this test had not been met, "the balancing approach of Goldberg and similar cases was not available to allow the teacher to claim appropriate procedural safeguards. The application of the test to "property" interests in the context of employee dismissals was reconsidered by the Supreme Court in the recent case of Arnett v. Kennedy, ${ }^{71}$ where a nonprobationary federal employee challenged his dismissal on the ground that the available pretermination procedures were insufficient to satisfy the due process clause. ${ }^{72}$ In denying the enployee's request for certain procedural safeguards, ${ }^{73}$ ?a three-judge plurality of the Court acknowledged the existence of a statutory "property" right (continued employment absent cause for dismissal). However, the plurality stated that an employee facing dismissal was entitled only to those specific procedural protections which the statute granting this right provided:

[T] he very section of the statute which granted him that right . . . expressly provided also for the procedure by which "cause" was to be determined, and expressly omitted the procedural guarantees which appellee insists are mandated by the Constitution. . . .

contract under state law would have an entitlement to continued employment and thus could not be dismissed without complance with certain due process safeguards.

71. 416 U.S. 134 (1974).

72. The employee in Arnett had been removed pursuant to the Lloyd-LaFollette Act, 5 U.S.C. $\$ 7501$ (a) (1970), which provides that "[a]n individual in the competitive service may be removed or suspended without pay only for such cause as will promote the efficiency of the service." The same statute, in subsection (b), set forth the procedures to be followed in determining the legitimacy of an einployee dismissal:

(b) An individual in the competitive service whose removal or suspension without pay is sought is entitled to reasons in writing and tohim;

(1) notice of the action sought and of any charges preferred against

(2) a copy of the charges;

(3) a reasonable time for filing a written answer to the charges, with affidavits; and

(4) a written decision on the answer at the earliest practicable date.

Examination of witnesses, trial, or hearing is not required but may be provided in the discretion of the individual directing the removal of suspension without pay. Copies of the charges, the notice of hearing, the answer, the reasons for and the order of removal or suspension without pay, and also the reasons for reduction in grade or pay, shall be made a part of the records of the employing agency, and, on request, shall be furnished to the individual affected and to the Civil Service Commission. Id. § 7501(b).

73. Dissatisfied with the statutory pretermination procedures which were available to him, see note 72 supra, the employee failed to answer the substantive charges against him but instead alleged that he was entitled to a trial-type hearing before an impartial official. He also contended that his dismissal was in fact due to his exercise of protected first amendment rights, 416 U.S. at 137-38. The district court agreed with him as to the procedural due process' issue and furthermore held the statutory and administrative ģuidelines regulating employees' speech to be unconstitutionally vague. Id. at 139 . 
... [W] [Were the grant of a substantive right is inextricably intertwined with the limitations on the procedures which are to be employed in determining that right, a litigant in the position of appellee must take the bitter with the sweet. ${ }^{74}$

A broad reading of the plurality opinion in Arnett would suggest the principle that, whenever a state creates a substantive right and at the saine tinie grants a procedure to protect that right, the nature of the right is conclusively defined as excluding other procedural safeguards. It is uncertain what exceptions might be made-for example, whether in a given case the procedures granted could be deemed so clearly inadequate to protect the right created that further safeguards could be ordered by a court. ${ }^{75}$

Another recent case revealed that "liberty" interests can be covered by the entitlement doctrine as well. In Wolff $v . \mathrm{McDonnell}^{76}$ the Court required that minimal due process guarantees be observed before inmates of a state prison are deprived of their statutory "good time" credits. The Court stated: "The Court has consistently held that some kind of hearing is required at some time before a person is finally deprived of his propenty interests . . . . We think a person's liberty is equally protected even where the liberty itself is a statutory creation of the State."7t

74. Id. at 152-54.

75. Justice Marshall's dissent in Arnett pointed to occasions in the past where the Court held inadequate the procedures that had been provided by statute:

Courts once considered procedural due process protections inapplicable to welfare on much the same theory-that "in accepting charity, the appellant has consented to the provisions of the law under which charity is bestowed." Obviously this Court rejected that reasoning in Goldberg . . . where we held that conditions under which public assistance was afforded, which did not include a pretermination hearing, were violative of due process. 416 U.S. at 210 (Marshall, J., dissenting) (citations omitted).

Justice Marshall pointed also to the Morrissey decision where the statute which provided for the limited grant of liberty was struck down because it also provided that that liberty could be revoked without a hearing. Id. See notes 88-90 infra and accompanying text. "In none of these cases did the Court consider a statutory procedure to be an inherent limitation on the statutorily created hiberty or property interest." Id. at 211.

76. 94 S. Ct. 2963 (1974).

77. Id. at 2975-76 (citations omitted). However, in Wolff the majority indicated in a footnote that due process would also apply to the imposition of other sorts of punishment such as solitary confinement. Id. at $2982 \mathrm{n} .19$. Yet there is no indication that the state in Wolff had defined any right, statutory or otherwise, not to be placed in solitary confinement. The dissent in Wolff concluded that "[t]he Conrt apparently holds that inmates' 'liberty' is protected by due process whenever 'a major change in the conditions of confinement' is imposed as punishment for misconduct." Id. at $2987 \mathrm{n.1}$ (Marshall, J., dissenting) (emphasis added). This is essentially a rephrasing of the "grievous loss" test. See note 56 supra and accompanying text. For a consideration of the possible applicability of this analysis to parole release decisions, see notes 113-22 infra and accompanying text. 
In essence, then, as to "property" interests and certain types of "liberty" interests, the entitlement doctrine has replaced the right-privilege distinction with a requirement not easily distinguishable from it: ${ }^{78}$ The claimed benefit must be a right under state law in order to qualify for due process protection.

\section{Present Enjoyment}

The Supreme Court has also approved the principle that an interest is protected only when it is presently enjoyed by the litigant: "The Fourteenth Amendment's procedural protection of property is a safeguard of the security of interests that a person has already acquired in specific benefits." It It will be noted, however, that this language refers only to "property" interests; in fact, the Court has never explicitly applied the present enjoyment test to determine whether "liberty" interests are entitled to due process protection. ${ }^{80}$ This omission might possibly form the basis for exempting a large number of important "nonproperty" interests from the requirements of the present enjoyment doctrine. However, if the use in the Constitution of the word "deprive" 81 is the foundation for this doctrine, the rationale of Roth is equally applicable to "liberty" interests.

The exact interrelationship of the "entitlement" and "present enjoyment" doctrines is not yet clear. Specifically, the Court has not yet decided whether the "present enjoyinent" restriction can be an alternative requirement (in the sense that some form of due process imight attach if the claimant established that he was presently enjoying a benefit to which he was not entitled) or whether it is merely a supplemental requirement to be met once the entitlement brancl of the test has been satisfied. ${ }^{82}$ It is reasonably certain, however, that at least as to

78. See Entitlement, Enjoyment, and Due Process $98-99$.

79. Board of Regents of State Colleges v. Roth, 408 U.S. 564, 576 (1972) (emphasis added). See also Bell v. Burson, 402 U.S. 535, 539 (1971); Scarpa v. United States Bd. of Parole, 477 F.2d 278, 282 (5th Cir. 1973); Menechino v. Oswald, 430 F.2d 403, 408 (2d Cir. 1970), cert. denied, 400 U.S. 1023 (1971).

80. However, in discussing the nature of a parolee's interest, the Supreme Court in Morrissey v. Brewer, 408 U.S. 471 (1972) approvingly cited a lower court's distinction between the importance of a parolee's imterest in conditional freedom and an inmate's hope of future freedom after a parole release hearing. This citation may indicate the Court's acknowledgment of the present enjoyment test's applicability to "Hiberty" interests. Nevertheless, another possible interpretation is that this quotation was intended to be part of the discussion of the quantum of due process procedural safeguards which should apply to the parole revocation proceeding rather than to indicate why a parolee's interest was protected by due process. See notes 98-100 infra and accompanying text.

81. "[N]or shall any State deprive any person of life, liberty, or property without due process of law . . . ." U.S. CoNST. amend. XIV.

82. See Entitlement, Enjoyment, and Due Process 101 \& n.55. In the pre-Roth 
property interests, the latter description is true and that a litigant whose interest was not presently enjoyed by him at the time of the state's action will not be aided by due process safeguards.

The emerging doctrine has been criticized by both judges and commentators. In particular, the claim has been made that the entitlement doctrine is merely the discredited right-privilege distinction with trivial alterations ${ }^{83}$ and that its logical foundations are suspect. ${ }^{84}$ Attention has been drawn to the fact that the present enjoyment doctrine in practice produces unconscionable results: A person who has received a specific benefit is protected by the due process clause while a mere claimant or applicant, whose need for the same benefit may be just as great as, if not greater than, that of the recipient, is, left unprotected because of the present enjoyment docrtine. ${ }^{85}$ For that reason, it is argued, the current test does not adequately measure the interests under adjudication, as the same relative weight of government and individual interests leads to opposite holdings in different cases. ${ }^{86}$ Despite

case of Menechino v. Oswald, 430 F.2d 403 (2d Cir. 1970), cert. denied, 400 U.S. 1023 (1971), the Second Circuit Court of Appeals suggested that an interest protected by constitutional due process could be either "a private interest enjoyed by appellant, or to which he is entitled," 430 F.2d at 408 (emphasis added), thus indicating a view that the "present enjoyment" doctrine alone might support a claim to due process protection.

83. See Entitlement, Enjoyment, and Due Process 98-99.

84. Great emphasis has been laid upon the discretion which the states enjoy under the entitlement doctrine to define the interests which are protected by due process. It is argued that the due process clause was certainly intended to place some limitations upon such state discretion. See Entitlement, Enjoyment, and Due Process 103-11. The fears implicit in this contention are given increased relevance by the recent case of Arnett v. Kennedy, 416 U.S. 134 (1974), where a plurality of the Supreme Court interpreted the entitlement doctrine as giving the states the power to define the procedural safeguards which an individual can claim to protect his substantive state-created rights. See notes 71-75 supra and accompanying text.

85. See Entitlement, Enjoyment, and Due Process 112-13. "Deprivation is not a one-time occurrence that begins and ends at the moment when something is withdrawn; rather, it occurs continuously until the benefit that is the subject of the deprivation is restored or conferred." Id. at 113 n.96. Cases such as Goldberg v. Kelly, 397 U.S. 254 (1970) (due process must be observed before termination of welfare benefits), and Bell v. Burson, 402 U.S. 535 (1971) (applying due process protections to driver's license revocations), are no less appealing under an "interest" approach when the facts are changed to cast the plaintiffs in the roles of applicants rather than prior recipients. In Goldberg, the Court emphasized the "brutal need" which might be faced by the welfare recipients if their benefits were stopped, 397 U.S. at 261, a consideration equally as relevant if needy applicants are denied benefits. Similarly, the Court's argument in Bell that a driver's license might be "essential in the pursuit of a livelihood," 402 U.S. at 539 , is applicable as well to persons seeking such licenses.

86. The inadequacy of the present enjoyment distinction was recognized in recent decisions regarding parole release. Bradford v. Weinstein, No. 73-1751 (4th Cir. Nov. 22, 1974); United States ex rel. Johnson v. Chairman of N.Y. State Bd. of 
the persuasive force of these criticisms, however, it is obvious that the qualifying test herein described is deeply embedded in current constitutional doctrine and must be considered in every evaluation of a particular interest's status under the due process clauses.

\section{Application of the Due Process Qualifying Test to Parole Release Hearings}

It is the conclusion of this Comment that the interest of a prisoner in prospective parole would not qualify for protection under the strictest application of the above-1nentioned due process test. Regardless of how such an interest is characterized, it is evidently not one of the preferred rights, such as freedoin of speech, which are automatically treated as protected interests. ${ }^{87}$ Nor does this interest satisfy the dootrines of entitlement and present enjoyment. The factors which distinguish parole release decisions from other contexts where protection has been granted are obvious. In Morrissey $v$. Brewer, ${ }^{88}$ for example, the Supreme Court held that due process requirements must be observed at parole revocation hearings. ${ }^{89}$ The "conditional liberty" of a parolee facing parole revocation, unlike the mere hopes of a prisoner for parole release, is a presently enjoyed interest. ${ }^{90}$ And in Wolff $v$. McDonnell, ${ }^{91}$ where the Court held that procedural safeguards were mandated at certain prison disciplinary hearings, ${ }^{92}$ the determining factor was the prisoner's statutory entitlement to good time credits. ${ }^{93}$ By contrast, no statute currently in force entitles a prisoner to be released on parole before the expiration of his sentence. ${ }^{94}$

Parole, 500 F.2d 925 (2d Cir.), vacated as moot sub nom. Regan v. Johnson, 43 U.S.L.W. 3294 (U.S. Nov. 19, 1974) (No. 74-108); Childs v. United States Bd. of Parole, No. 74-1052 (D.C. Cir. Dec. 19, 1974). See notes 101-23 infra and accompanying text.

87. The imterest of an inmate facing a parole release proceeding does not explicitly appear in the text of the Bill of Rights, nor could it be said to qualify as a natural right such as the right to privacy. In addition, there is no indication that the interest affected in a parole release hearing would be regarded as "fundamental" so as to become a substantive due process right. See note 68 supra and accompanying text.

88. 408 U.S. 471 (1972).

89. Id. at 482.

90. See notes 104-08 infra and accompauying text. For the possibility that "liberty" interests, such as parole release, might be exempted from the strict "present enjoyment" requirement, see notes 80-81 supra and 113-21 infra and accoinpanying text.

91. 94 S. Ct. 2963 (1974).

92. Id. at 2976.

93. Id. at 2975. But see note 77 supra.

94. Inmates, other than those whose request for parole is based on accumulated good time credits which automatically advance the date of release, have no claim of a right to be paroled since the decision of the parole board in all jurisdictions is discre- 
Such has been the analysis in many of the courts which have confronted the issue of whether parole release decisions qualify for due process protection. Even prior to the Supreme Court's decisions in Roth and Perry, the Second Circuit in Menechino v. Oswald ${ }^{95}$ explained that procedural due process protects only those interests that are presently enjoyed and that a prisoner

does not presently enjoy freedom of movement beyond the prison walls and nothing in the state court's sentence, or in state statutes or rules entitles him to it, whether it be called a "right" or a "privilege." ... Appellant has been constitutionally deprived of his right to hiberty for the period of his sentence. Like an alien seeking entry into the United States (as distinguished from a lawful resident alien) he does not qualify for procedural due process in seeking parole. ${ }^{96}$

Similarly, in United States ex rel. Bey v. Connecticut State Board of Parole, ${ }^{07}$ the same court explicitly distinguished parole revocation and parole release hearings under the doctrine of present enjoyment: "It is not sophistic to attach greater importance to a person's justifiable reliance on mamtaining his conditional freedoin ... than to his mere anticipation or hope of freedom." not ruled on the issue of whether parole release proceedings require due process guarantees, the Court in Morrissey approvingly cited this statement in $B e y,{ }^{90}$ perhaps indicating a view that parole release decisions, unlike parole revocation hearimgs, would not merit this protection. ${ }^{100}$

tionary. The discretionary nature of the decision is underscored by the vague statutory criteria by which the parole boards are bound. See notes 9-11 supra and accompanying text. For an example of a proposed statute which would create a statutory entitlement to release upon the date of a prisoner's initial eligibility for parole, see notes 181-82 infra and accompanying text.

95. 430 F.2d 403 (2d Cir. 1970), cert. denied, 400 U.S. 1023 (1971).

96. 430 F.2d at $408-09$ (emphasis added). See also Scarpa v. United States Bd. of Parole, 477 F.2d 278, 283 (5th Cir.), vacated as moot, 414 U.S. 809 (1973).

97. 443 F.2d 1079 (2d Cir.), vacated as moot sub nom. Connecticut State Bd. of Parole v. Bey, 404 U.S. 879 (1971) (inmate entitled to assistance of counsel in parole revocation hearings).

98. Id. at 1086. Contra, United States ex rel. Johnson v. Chairman of N.Y. State Bd. of Parole, 500 F.2d 925, 928 (2d Cir.), vacated as moot sub nom. Regan v. Johnson, 43 U.S.L.W. 3294 (U.S. Nov. 19, 1974) (No. 74-108).

99. 408 U.S. at 482 n.8.

100. See United States ex rel. Johnson v. Chairman of N.Y. State Bd. of Parole, 500 F.2d 925, 936 (2d Cir.), vacated as moot sub nom. Regan v. Johnson, 43 U.S.L.W. 3294 (U.S. Nov. 19, 1974) (No. 74-108) (Hays, J., dissenting). However, the Supreme Court's use of this quotation may merely be an indication that prisoners in parole release proceedings are not to be afforded the same quantum of rights as parolees facing revocation. See 500 F.2d at 927-28 n.2; Childs v. United States Bd. of Parole, 371 F. Supp. 1246 (D.D.C. 1973), aff'd in part, vacated in part, No. 74-1052 (D.C. Cir. Dec. 19, 1974). 
Nevertheless, three circuit courts, including the Second Circuit Court of Appeals, have recently held that, on the basis of the Morrissey decision, parole release proceedings do qualify for due process protection. ${ }^{101}$ However, these courts either misunderstood the rigid requirements of the Supreme Court's due process qualifying test or failed to explain adequately their refusal to apply it in the parole release context. The District Court for the District of Columbia said in Childs v. United States Board of Parole:"102 "Whatever may be said for the decisions which have dealt with [parole release] and/or related questions involving due process requirements and the parole application stage, . . . it seems fair to say that the slate has been wiped all but clean by Morrissey v. Brewer ...."103 Morrissey had stated that parole was "an integral part of the penological systein" and was to be seen not as a "privilege" but rather as a "conditional liberty"104 qualifying for due process protection. The Second Circuit, relying on this language, held in United States ex rel. Johnson v. Chairman of New York State Board of Parole: $:^{105}$

A prisoner's interest in prospective parole or "conditional entitlement," must be treated in like fashion. To hold otherwise would be to create a distimction too gossamer-thin to stand close analysis. Whether the immediate issue be release or revocation, the stakes are the same: conditional freedom versus incarceration. ${ }^{108}$

101. Childs v. United States Bd. of Parole, No. 74-1052 (D.C. Cir. Dec. 19, 1974); Bradford v. Weinstein, No. 73-1751 (4th Cir. Nov. 22, 1974); United States ex rel. Johnson v. Chairman of N.Y. State Bd. of Parole, 500 F.2d 925 (2d Cir.), vacated as moot sub nom. Regan v. Johnson, 43 U.S.L.W. 3294 (U.S. Nov. 19, 1974) (No. 74108). See also Candarini v. Attorney General of the Uuited States, 369 F. Supp. 1132 (E.D.N.Y. 1974); United States ex rel. Harrison v. Pace, 357 F. Supp. 354 (E.D. Pa. 1973).

102. 371 F. Supp. 1246 (D.D.C. 1973), aff'd in part, vacated in part, No. 74-1052 (D.C. Cir. Dec. 19, 1974).

103. Id. at 1246-47. The court then held that due process must apply to parole release proceedings, using an analysis similar to that of the Second Circuit in Johnson. See id. at 1247.

104. 408 U.S. at 477 . The liberty experienced by a parolee is "conditional liberty" because the individual is subject to certain conditions of parole and may be returned to the correctional institution upon a finding that he has violated any of these conditions. For an evaluation of the validity of parole release conditions, see The Parole System 307-39.

105. 500 F.2d 925 ( $2 \mathrm{~d}$ Cir.), vacated as moot sub nom. Regan v. Johnson, 43 U.S.L.W. 3294 (U.S. Nov. 19, 1974) (No. 74-108).

106. Id. at 928 (emphasis added). Both the Childs court and the Johnson court acknowledged the language in Morrissey which placed the importance of parole revocation above that of parole release, see text accompanying note 99 supra, but found that this language did not pertain to the question of whether due process should apply to either proceeding, but how much should apply. See note 100 supra and accompanying text. Contra, Scarpa v. United States Bd. of Parole, 477 F.2d 278, 282 (5th Cir.), vacated as moot, 414 U.S. 809 (1973). 
Thus, the Second Circuit (and the District of Columbia Circuit in Childs) chose not to recognize the technical difference between a parolee who is enjoying conditional liberty and a prospective parolee who, due to the discretion of the parole board, has no right to demand his freedom under any circumstances. The courts' dissatisfaction with the result of this distimction is well founded; ${ }^{107}$ the present enjoyment analysis does not neasure the actual extent of injury which is experienced by either the parolee when parole is revoked or the prospective parolee when parole is demed. ${ }^{108}$

However, the Johnson and Childs courts failed to address themselves adequately to the requirements of the entitlement branch of the due process qualifying test. The Second Circuit in Johnson apparently felt that the entitlement requirement might be satisfied by a strong expectation:

Our view [that parole release proceedings are entitled to due process protection] is strengthened by the fact that most inmates in New York can expect parole. ... [T] The average prisoner, having a better than $50 \%$ chance of being granted parole before the expiration of his maximum sentence, has a substantial "interest" in the outcome. For him, with such a large stake, the Board's determination represents one of the most critical decisions that can affect his life and liberty. ${ }^{109}$

However, the Supreme Court made it clear in Roth that one "must have more than a unilateral expectation of [a benefit]" in order that the benefit be considered a property interest protected by the due process clause. ${ }^{110}$ The Roth Court also explicitly rejected the argument that a better-than-average chance of receiving a benefit would create an entitlement. ${ }^{111}$ Since the decision of the board is ultimately one of discre-

107. Actually, the question in both situations is the enjoyment of "conditional liberty" in the future. Whether it is continued liberty or an initial grant thereof seems to be of little consequence as regards the inpact of the decision upon the individual being considered. The commentators have generally supported this view. See ParsonsLewis 1539-40; The Parole System 366-67. For a general discussion of the current test's failure to weigh opposing interests, see notes 85-86 supra and accompanying text.

108. See notes 85-86 supra and accompanying text.

109. 500 F.2d at 928. Phrasing the inmates' expectation as 'conditional entitlement," the court listed the following statistics and sources:

Fifty-four percent of all prisoners released from prison in 1970, according to 46 reporting jurisdictions left as parolees. Kastenheimer \& Eglil, Parole Release Decision-Making: Rehabilitation, Expertise, and the Demise of Mythology, 22 Amer. U.L. Rev. 477, 481 (1973). In New York the figure is even higher. In 1972, for instance, the New York State Parole Board released 4,412 inmates on parole, or $75.4 \%$ of the cases coming before it. See "Report on New York Parole" by Citizens' Inquiry on Parole and Criminal Justice, Inc.

(1974), 48. 500 F.2d at 928.

110. 408 U.S. at 577.

111. Id. at 577-78. The Court noted that, although most teachers at the state university were in fact rehired, this would not amount to a claim of entitlement, absent 
tion, there thus being no guarantee of the outcoine, the expectation of an inmate falls short of the "legitimate claim of entitlement" which Roth held to be necessary before due process would attach. ${ }^{112}$

Recently, the Fourth Circuit held in Bradford v. Weinstein ${ }^{113}$ that parole release proceedings qualify for limited due process guarantees. ${ }^{114}$ As a basis for this decision, the court found that a prospective parolee had an interest in "liberty"115 protected by the fourteenth amendment. The restrictive language in Roth was rejected as dealing solely with "property" interests;, joyment test was not required. Although the nature of the Bradford "liberty" interest is not entirely clear, ${ }^{117}$ the court seems to have concluded that the "grievous loss" analysis provided the appropriate standard for measuring a "liberty" interest. Instead of relying upon Roth, the Bradford court strongly emphasized the inore recent Supreme Court decision of Wolff $v$. McDonnell, ${ }^{118}$ which extended procedural protections to the deprivation of inmates' good time credits. Although the Wolff majority explicitly based its holding upon the prisoners' statutory entitlement to such credits, the dissenters stated that the inajority

state decisional or statutory support for such a theory. Id. at $578 \mathrm{n.16}$; $c$. Perry v. Sindermann, 408 U.S. 593, 602 (1972), where the Court recognized the possibility of such an implied tenure agreement.

112. 408 U.S. at 577. See note 69 supra and accompanying text.

113. No. 73-1751 (4th Cir. Nov. 22, 1974).

114. Id. at 11. The court remanded the case to the district court to determine precisely which procedural safeguards were required.

115. Id. at 9 .

116. See note 80 supra and accompanying text. The Bradford court noted:

Roth and Sindermann did little to provide a definitive definition of "liberty" which we could easily apply .... Roth did say that "l,berty" protected by due process extends "beyond the soit of formal constraints imposed by the criminal process" and that the term is "not confined to mere freedom from bodily restraint." Id. at 8-9, citing Board of Regents of State Colleges v. Roth, 408 U.S. 564, 572 (1972), quoting Bolling v. Sharpe, 347 U.S. 497, 499 (1954).

117. The court mentioned that the inmate had both a right to be considered for parole when he is statutorily eligible for early release and a privilege to be granted that early release. No. 73-1751 at 8. As to the former, the court relied upon a North Carolina statute which explicitly states that the provisions for parole eligibility "shall [not] be construed as making mandatory the release of any prisoner on parole, but shall be construed as only guaranteeing to every prisoner a review and consideration of his case upon the merits." 3C N.C. GEN. STAT. \$ 148-58 (1974) (emphasis added). The decision is also based upon a South Carolina statute (the decision is a consolidation of two appeals) which defines when an innate is eligible for parole but grants no right to be considered for parole. S.C. CODE ANN., ch. 11, § 55-611 (Supp. 1973). See No. 73-1751 at 7 n.2. However, in the court's analysis as to the nature of the inmate's interest, it speaks more in terms of the inmate's privilege than of his right. Probably the existence of a right to be considered for parole gives increased importance to the proceeding which may grant him the privilege to be paroled.

118. 94 S. Ct. 2963 (1974). 
had actually adopted the "grievous loss" analysis in the case of "liberty" interests. ${ }^{110}$ The Bradford court apparently accepted the dissenters' characterization of the Wolff holding by applying the "grievous loss" test to parole release decisions. ${ }^{120}$ In so doing, the court overlooked the fact that Roth expressly rejected the "grievous loss" itest with respect to both liberty and property interests. Presumably, the analysis of Bradford (and of the Wolff dissenters) would be that the statement in Roth has been modified as to "liberty" interests by the majority opinion in Wolff.

If the Supreme Court were to adopt the analysis of the Johnson, Childs, and Bradford courts and hold that an inmate's interest in the conditional liberty of parole should not be defeated by the present enjoyment doctrine, due process protection would necessarily attach to parole release hearings. The loss experienced by a prisoner wlio is demed parole is necessarily as "grievous" as that of the parolee in Morrissey. ${ }^{121}$ However, in order to give some effect to its approval of the distinction between parolees and prospective parolees in Morrissey, ${ }^{122}$ the Court would probably hold that the safeguards to be observed at parole release proceedings need not be as strict as those imposed upon parole revocation hearings by the Morrissey Court. For

119. See note 77 supra.

120. In explaining its reliance upon Wolff, the court in Bradford reasoned:

The case [of parole release decisions] is really the converse of Wolff. There, one who was cenfined was subjected to the risk of durance more vile; here, one who is confined is afforded the right of consideration of partial release from restraint and the privilege of partial release. The first is a right not to be restrained; the second, the privilege of release from restraint. No. 73-1751 at 10 (emphasis in original).

The court then stated that the distinction was unimportant because of the rejection by the Supreme Court of the right-privilege distinction. Id., citing Board of Regents of State Colleges v. Roth, 408 U.S. 564, 571 (1972); Morrissey v. Brewer, 408 U.S. 471, 481 (1972); Graham v. Richardson, 403 U.S. 365, 374 (1971). See notes 33-35 supra and accompanying text. In determining that prospective parolees would have an interest which satisfies the "grievous loss" standard, the court specifically noted the ex parte nature of the parole release hearing, the possibilities of error, and the fact that without a statement of reasons a prisoner would have no idea of what changes might lead to a successful application for parole. See 73-1751 at 11 .

The "grievous loss" test harbors one apparent difficulty. The argument could be made that a prisoner who has failed to receive parole has not "lost" anything he ever had in the first instance. Also, under the language of the dissent in Wolff, see note 77 supra, a denial of parole would not be a "major change in the conditions of confinement," but rather a continuation of his sentence. The Childs court, however, thought denial of parole was in fact a deprivation of conditional liberty, and a parole applicant "either suffers a 'grievous loss' or gains conditional liberty." Childs v. United States Bd. of Parole, No. 74-1052 at 15 (D.C. Cir. Dec. 19, 1974). The Bradford court solved this potential problem by eliminating the present enjoyment requirement.

121. See note 106 supra and accompanying text.

122. See notes $98-100$ supra and accompanying text. 
this reason, even if "liberty" interests were exempted from the strict requirements of the "present enjoyment" analysis, legislative action would be necessary to secure more than minimal procedural protection.

It is at least equally probable that the Court would not limit the rigid requirements of Roth and Arnett to "property" interests and would adopt the Wolff majority's own description of its holding as being based upon a statutory entitlement rather than upon the general absence of a present enjoyment requirement as to "liberty" interests. If this analysis were adopted by the Court, it would necessarily follow the Second Circuit's earlier decision in Menechino v. Oswald ${ }^{123}$ and hold that a prisoner has no presently enjoyed interest in his prospective parole. Despite the manifest injustice of such a distinction, the result would be a complete denial of procedural protection at parole release hearings. Consequently, the lower courts would be precluded from fashioning safeguards by balancing the interests at stake. However, as the following section of this Comment will deinonstrate, even if the Supreme Court applies a strict imterpretation of the due process test, the prospective parolee will not necessarily be left without any degree of protection.

\section{Alternative Sources of Procedural Protection}

This section of the Comment will consider the availability of procedural guarantees, primarily the right to a statement of reasons for parole denial, which are not dependent upon bringing parole proceedings within the protection of the due process clauses.

\section{Existing Legislation}

It is axiomatic that an entitlement to specific procedural safeguards can be granted by legislation or by valid administrative regulations. In addition to the rare state legislation which has this effect, ${ }^{124}$ the federal prisoner can argue that the protections of the Administrative Procedure Act (APA) ${ }^{125}$ should be applicable. The APA is a compilation of the rights and procedures which federal agencies must respect in the performance of their functions. It applies to each agency of the United States except those specifically exempted by statute. $^{128}$

123. 430 F.2d 403 (2d Cir. 1970), cert. denied, 400 U.S. 1023 (1971). See notes 95-96 supra and accompanying text.

124. See notes 12, 14-15 supra and accompanying text.

125. 5 U.S.C. $\$ \S 551-59,701-06,1305,3105,3344$ (1970).

126. Agency is defined as "each authority of the Government of the United States." 5 U.S.C. $\$ 551(1)$ (1970). This provision goes on to enumerate eight organizations 
Some federal courts have been willing to apply the APA to parole release decisions, at least to a limited extent. ${ }^{127}$ Recently, in King $v$. United States, ${ }^{128}$ a prisoner suggested that the court should compel a federal parole board to give him the reasons for the denial of his parole apphication. ${ }^{129}$ Although the court wrote a lengthy discussion of the possibility of granting the claim on due process grounds, it ultimately relied on a construction of the APA as the basis for its decision. In order to avoid conflicting with earlier decisions that held the APA imapplicable to parole release proceedings, ${ }^{130}$ the King court relied on the statement of reasons requirement of the APA. ${ }^{131}$ This approach allowed the court to avoid the difficulty of attempting to review the parole board's discretion; the court explained that it had "jurisdiction to consider at least the plaintiff's statutory claim that the Board has disobeyed a nondiscretionary command that it provide reasons for its determination after exercising its discretion." ${ }^{132}$ The court noted that the statement of reasons section of the APA, unlike the APA provisions considered by earlier decisions, ${ }^{133}$ applies to any agency pro-

of the federal government not included within this definition. Parole boards are not mentioned in the list of exceptions.

127. See, e.g., Pickus v. United States Bd. of Parole, No. 73-1987 (D.C. Cir. Oct. 11, 1974); Mower v. Britton, 504 F.2d 396 (10th Cir. 1974); King v. United States, 492 F.2d 1337 (7th Cir. 1974); Hurley v. Reed, 288 F.2d 844 (D.C. Cir. 1961); Sobell v. Reed, 327 F. Supp. 1294 (S.D.N.Y. 1971).

128. 492 F.2d 1337 (7th Cir. 1974).

129. Id. at 1338.

130. See Hiatt v. Compagna 178 F.2d 42 (5th Cir. 1949) aff'd by an equally divided Court, 340 U.S. 880 (1950), which held that parole release decisions were exempt from the judicial review provisions of the APA which excuse those agencies whose actions are committed to discretion by law. See 5 U.S.C. \& 701(a)(2) (1970). However, the "discretion by law" exemption has been interpreted to mean that judicial review" is precluded to the extent that discretion has been exercised, but it is not prohibited where there has been abuse of discretion. See, e.g., Scanwell Laboratories, Inc. v. Shaffer, 424 F.2d 859 (D.C. Cir. 1970); Jones v. Freeman, 400 F.2d 383 (8th Cir. 1968); Bell Lines, Inc. v. United States, 306 F. Supp. 209 (S.D.W. Va. 1969), aff'd, 397 U.S. 818 (1970). See also Hyser v. Reed, 318 F.2d 225 (D.D.C. 1963), where Mr. Chief Justice (then Judge) Burger held that what is now section 554 of the APA (providing for procedural safeguards in agency adjudications) did not govern parole revocation proceedings. The court said that the provisions applied only to those agencies "which are required by their own statute of creation to adjudicate after hearing" and held that parole boards were not so required. 1d. at 237 (emphasis in original).

131. 5 U.S.C. $\$ 555(\mathrm{e})(1970)$. This section provides in part:

Prompt notice sball be given of the denial in whole or in part of a written application, petition, or other request of an interested person made in connection with any agency proceedings. Except in affirming a prior denial or when the denial is self-explanatory, the notice shall be accompanied by a brief statement of the grounds for denial.

132. $492 \mathrm{~F} .2 \mathrm{~d}$ at 1339.

133. Hiatt was concerned with 5 U.S.C. $\$ 701(a)(2)$ (agency action committed to 
ceeding. ${ }^{134}$ Furthermore, the court concluded that parole release hearings are agency proceedings within the $\mathrm{APA}^{135}$ and that nothing in the APA exeinpts parole proceedings from the application of the stateinent of reasons sections. ${ }^{136}$ Therefore, federal parole boards were required to provide a statement of reasons for the demal of parole. ${ }^{137}$

The APA was also used in Pickus v. United States Board of Parole $e^{138}$ to require the Parole Board to provide "advance public notice and opportunity for interested persons to participate through oral or written submission of data or opinion"139 in the development of regulations concerning federal parole hearings. ${ }^{140}$ The effect of this decision was to render the rules of the United States Board of Parole invalid because the Board had failed to comply with the APA's "public rulemaking proceeding." 141

These courts were correct in finding that parole release proceedings are within the general coverage of the APA. ${ }^{142}$ For this reason, the King analysis should be applicable to all APA provisions which require procedural safeguards in "any agency proceeding." 143 To this limited extent, then, federal prisoners will be able to obtain certain procedural guarantees without qualifying their interest in prospec-

agency discretion by law). Hyser, see note 130 supra, construed what is now 5 U.S.C.

$\S 554$ (a) (requirements for agency adjudications).

134. 492 F.2d at 1344.

135. Id. at 1344. The court in Pickus v. United States Bd. of Parole, No. 73-1987 at 7-9 (D.C. Cir. Oct. 11, 1974), was faced with this same issue. This court concluded that the parole board was an agency within the meaning of the APA. It reasoned: "Legislative history, though sparse, supports a broad, inclusive reading of the Act." Id. at 8.

When it published revised parole procedures about four months before Pickus was decided, the United States Board of Parole said that it "expressly disclaims that its rules are subject to the rulemaking provisions of the Administrative Procedure Act, 5 U.S.C. \$553(b)." 39 Fed. Reg. 20,028 (1974).

136. 492 F.2d at 1343.

137. Id. at 1345; accord, Mower v. Britton, 504 F.2d 396, 398 (10th Cir. 1974).

138. No. 73-1987 (D.C. Cir. Oct. 11, 1974).

139. Id. at 2.

140. Id. at 13 .

141. Id. at 2. This provision is section four of the APA. 5 U.S.C. $\$ 553$ (1970).

142. See K. Davis $\$ 16.09$, at 335-36 (1972). Professor Davis has long argued that parole release decisions are subject to this provision of the APA. See also Comment, supra note 20, at 481-83. But see Childs v. United States Bd. of Parole, No. 741052 at 18 (D.C. Cir. Dec. 19, 1974), where the court saw more than "one fruitful occasion for controversy" in the application of the APA to parole release proceedings.

143. See 5 U.S.C. $\$ 555$ (b) (1970), which provides that "A person compelled to appear in person before an agency or representative thereof is entitled to be accoinpanied, represented, and advised by counsel or, if permitted by the agency, by other qualified representative." 
tive parole under the due process test. However, there are few state statutes resembling these APA provisions, ${ }^{144}$ and even those may be construed so as to exempt parole release decisions. Therefore, the state prisoner must generally rely upon whatever protection is made available by his state's decisional law.

\section{Common Law Approaches}

The Supreme Court of New Jersey provided such relief in Monks v. New Jersey State Parole Board, ${ }^{145}$ which held that a parole board must give a statement of reasons upon demal of parole. ${ }^{146}$ The court based its decision not upon due process or a statutory requirement, but upon a common law principle of "fundamental fairness" in agency proceedings. ${ }^{147}$ The court stated that the court rules gave it the authority to review administrative agency actions to "insure procedural fairness in the administrative process and to curb administrative abuses." 148 In order to effect such review the court looked to its previous rulings and those of the United States Supreme Court which required that administrative agencies state their findings and reasons in order to "'[msure] a responsible and just determination' by the agency [and] also '[to afford] a proper basis for effective judicial review.' "149 Accordingly, the court applied this common law requirement to parole boards and parole release proceedings. ${ }^{150}$ Although Monks might be viewed as a legitimate example of the recent judicial tendency to impose administrative procedural safeguards, ${ }^{151}$ it is nevertheless an isolated instance in the area of parole release. The basic difficulty with such a common law approach is that the overwhelming majority of decisions which require administrative procedural safeguards have relied

144. See K. Davis $\S 16.07$, at 326. But see ANN. Laws of Mass., Ch. 30A § 11(8) (1973): "The decision shall be accompanied by a statement of reasons for the decision, including determination of each issue of fact or law necessary to the decision, unless the General Laws provide that the agency need not prepare such statement in the absence of a timely request to do so."

145. 58 N.J. 238, 277 A.2d 193 (1971).

146. Id. at 250,277 A.2d at 199 . On remand, the parole board decided to grant parole rather than supply a statement of reasons for its previous denial. See generally Parsons-Lewis 1536 n.86.

147. 58 N.J. at $244-46,277$ A.2d at $196-97$.

148. Id. at $249,277 \mathrm{~A} .2 \mathrm{~d}$ at 198.

149. Id. at 244-45, 277 A.2d at 196, citing Abbotts Dairies v. Armstrong, 14 N.J. 319 (1954); SEC v. Chenery Corp., 318 U.S. 80 (1943); see K. Davis $\$ 16.12$.

150. 58 N.J. at 249,277 A.2d at 198 . The court struck down the parole board's rule that it would not reveal the basis for a denial of parole. Id.

151. See K. Davis $\S \S 2.06-.10$. Under state and federal common law, courts are moving away from an emphasis upon establishing administrative standards toward an emphasis upon administrative safeguards. See id. at 40-41 \& n.16. 
upon a due process analysis. In these precedents, the litigant's interest was such that it satisfied the entitlement and present enjoyment requirements. ${ }^{152}$ Courts may be reluctant to apply sucli safeguards to other administrative proceedings where the litigant cannot satisfy the due process qualifying test. ${ }^{153}$ These considerations greatly diminish the importance of Monks for parole applicants in other states. It should also be noted that the only safeguard provided was the limited requirement that a board state its reasons for rejecting a parole application. ${ }^{154}$

Another state supreme court employed a different analysis in requiring a statement of reasons upon denial of parole. In In re Sturm, ${ }^{155}$ the Supreme Court of California held that an inmate facing a parole release hearing was "entitled to liave his application 'duly considered." "156 Although the court acknowledged the discretionary nature of a parole decision, it held that such discretion must be exercised "in good faith, neither arbitrarily nor capriciously."157 The court then reasoned that under "time-honored priniciples of common law, ...

152. See, e.g., Perry v. Sinderman, 408 U.S. 593 (1972); Morrissey v. Brewer, 408 U.S. 471 (1972).

153. But see K. Davis $\S 2.09$, at 46-47. Professor Davis speaks of the "Threshold of a New Era" in administrative law where courts will be more active in imposing procedural safeguards, and he cites a number of cases which illustrate the new trend. See Holmes v. New York City Housing Authority, 398 F.2d 262 (2d Cir. 1968) (requiring that an agency establish standards for selecting among applicants). However, these cases are reasoned in tenns of due process. Further, they were decided before the more stringent standards of the due process qualifying tests were established under Board of Regents of State Colleges v. Roth, 408 U.S. 576 (1972). See notes 62-64 supra and accompanying text. Although Professor Davis argues that the new trend may move away from a constitutional base to a common law base, K. DAvs $\$ 2.09$, at 47 , it is quite possible that such cases would not reach the same holdings today upon the constitutional basis under the due process tests.

154. 58 N.J. at 249-50, 277 A.2d at 199.

155. 11 Cal. 3d 258, 521 P.2d 97, 113 Cal. Rptr. 361 (1974).

156. Id. at 268, 521 P.2d at 103, 113 Cal. Rptr. at 367, citing In re Schoengarth, 66 Cal. 2d 295, 425 P.2d 200, 57 Cal. Rptr. 600 (1967).

157. $11 \mathrm{Cal} .3 \mathrm{~d}$ at $268,521 \mathrm{P} .2 \mathrm{~d}$ at 103, $113 \mathrm{Cal}$. Rptr. at 367, citing Roberts v. Duffy, 167 Cal. $629,640,140$ P. 260, 264 (1914). Roberts noted that the board's discretion must be exercised to reach a "fair and just conclusion." Id. This holding is based upon the state statute giving the Adult Authority (parole board) the power to decide when an inmate should be paroled. See CAL. PENAL CODE $\$ 3040$ (West 1970). A similar conclusion that parole decisions must not be made in an arbitrary nanner has been reached by other courts. See United States ex rel. McCreary v. Kenton, 190 F. Supp. 689, 691 (D. Conn. 1960) (parole revocation): "Of course, the Parole Board, like other bodies vested with power to exercise discretion, must have some reasonable basis for inaking its determinations. It cannot act arbitrarily or heedlessly, or through whim or caprice." 
the parole applicant's right to 'due consideration' cannot exist in any practical sense unless there also exists a remedy against [its] abrogation."158 The Sturm court therefore held that some procedural protection was necessary, as a practical matter, to enable an inmate to vindicate his right to a nonarbitrary decision. Specifically, in order for the prisoner to make a persuasive request for relief from an arbitrary decision, he must know of the reasons why parole was denied. ${ }^{159}$ In addition, effective judicial review would be impossible unless the courts were made aware of the reasons for the board's action. ${ }^{160}$ Accordingly, a statement of reasons was held necessary to allow meaningful judicial review of the litigant's right to secure a fair parole release decision. ${ }^{101}$

This analysis, which is independent of the question whether parole release decisions satisfy the due process qualifying test, could conceivably be applied by other courts. ${ }^{162}$ However, even if it were generally accepted, the argument has severe limitations, as it would not apply to other procedural safeguards, such as the right to counsel, which have a more tenuous relationship, if any, with the court's ability to review a parole board decision. ${ }^{103}$

158. 11 Cal. 3d at 268, 521 P.2d at 104, 113 Cal. Rptr. at 368 .

159. Id. at 272, 521 P.2d at 106, 113 Cal. Rptr. at 370.

160. Id.; see United States ex rel. Johnson v. Chairman of N.Y. State Bd. of Parole, 500 F.2d 925,929 (2d Cir.), vacated as moot sub nom. Regan v. Johnson, 43 U.S.L.W. 3294 (U.S. Nov. 19, 1974) (No. 74-108).

161. 11 Cal. $3 d$ at 273,521 P.2d at $107,113 \mathrm{Cal}$. Rptr. at 371 . A similar analysis was made in Kent v. United States, 383 U.S. 541 (1966), regarding juvenile proceedings. There, after a juvenile had been arrested for robbery and rape, the case was tried in a district court after a juvenile court had summarily waived its exclusive jurisdiction. Such an order precluded the juvenile from receiving reformative sentencing. Recognizing the juvenile court's broad discretion in the decision, the court found that due process and fairness as well as the statutory requirement of a "full investigation" precluded the exercise of that discretion in an arbitrary fashion. Id. at 553. A statement of reasons was deemed necessary for meaningful review (where arbitrariness was clained) and to assure that the action of the juvenile court was carefully considered in the first instance. Id. at 554. Although the Court in Kent did rely upon the statutory requirement, lower courts have looked to Kent for the proposition that the due process claim to fairness requires that certain procedural rights such as the use of a statement of reasons be observed to avoid the arbitrary exercise of discretionary power. See Powell v. Hocker, 453 F.2d 652, 654 (9th Cir. 1971) (dealing with the right to notice, assistance of counsel, and a statement of reasons in a proceeding to determine whether an inmate will be tried as an adult). See also Bland v. United States, 412 U.S. 909, 910-13 (1973), denying cert. to 472 F.2d 1329 (D.C. Cir. 1972) (Douglas, J., dissenting); In re Sturm, 11 Cal. 3d at 268 n.13, 521 P.2d at 104-05 n.13, 113 Cal. Rptr. at 368-69 n.13.

162. See note 157 supra.

163. In Dorado v. Kerr, 454 F.2d 892 (9th Cir.), cert. denied, 409 U.S. 934 (1972), prisoners argued that under California parole law, the same law construed in Sturm, they 


\section{The Mempa Analysis}

A final approach which would not depend on the nature of a prisoner's interest in prospective parole might attempt to secure the procedural safeguard of the right to counsel provided by the sixth amendment. ${ }^{164}$ Although this argument has yet to be adopted by any court, it has found some support among the commentators. ${ }^{105}$ The precedent rehed upon is Mempa $v$. Rhay, ${ }^{160}$ in which the Supreme Court determined that counsel must be afforded at a sentencing which had been deferred subject to probation. ${ }^{107}$ Sentencing was seen as a "critical stage" in a criminal case, ${ }^{108}$ and counsel was held to be necessary to ensure that the sentence was not based on misinformation and that other rights were protected. ${ }^{109}$ Relying on $M e m p a$, the petitioner in Briguglio v. New York State Board of Parole, ${ }^{170}$ claimed that a parole release decision was a form of deferred sentencing and that he was therefore entitled to due process protection in a parole board's consideration of his release. However, the court in Briguglio limited Mempa to its facts as a "sentencing" case and found that since Brigugho had already been sentenced, Mempa was of little value in determining his rights. ${ }^{171}$ In addition, the Supreme Court in Morrissey $v$. Brewer distinguished Mempa by noting that parole revocation was

had a right to (1) assistance of counsel, (2) access to the prisoners' cumulative records, (3) a full record of review proceedings, and (4) written decisions stating the evidence upon which the determination was based. Id. at 894 . The Ninth Circuit affirmed the dismissal of this complaint for failure to state a cause of action.

164. U.S. CoNST. amend. VI provides in part: "In all criminal prosecutions the accused shall enjoy the right . . . to have the assistance of counsel for his defense." (Emphasis added.)

165. See Parsons-Lewis 1533-37; Comment, Due Process: The Right to Counsel in Parole Release Hearings, 54 Iowa L. REv. 497, 506-07 (1968).

166. 389 U.S. 128 (1967).

167. Id. at 137. The petitioners in Mempa had been originally granted probation, and the sentencing in question took place as a result of the revocation of their probation for alleged violations. It may be inferred from the holding in Mempa that due process must also apply in the original sentencing procedures. See Note, Procedural Due Process at Judicial Sentencing for Felony, 81 HARv. L. REv. 821, 834-35 (1968). However, the exact incidents of due process which should apply have yet to be determined. See McGautha v. California, 402 U.S. 183, 218 (1971), when the court stated that it "has not directly [been] determmed whether or to what extent the concept of due process of law requires that a criminal defendant wishing to present evidence or arguinent presumably relevant to the issues involved in sentencing should be permitted to do so."

168. 389 U.S. at 133-34.

169. Id. at 133; cf. Townsend v. Burke, 334 U.S. 736 (1948).

170. 24 N.Y.2d 21, 246 N.E.2d 512, 298 N.Y.S.2d 704 (1969).

171. Id. at 24,246 N.E.2d at 514, 298 N.Y.S.2d at 707. See also Dorado v. Kerr, 454 F.2d 892, 896 (9th Cir. 1972), cert. denied, 409 U.S. 934 (1972); Menechino v. Oswald, 430 F.2d 403, 410 (2d Cir. 1970), cert. denied, 400 U.S. 1023 (1971). 
not part of a "criminal prosecution", ${ }^{172}$ parole release proceedings would probably be viewed in the same manner, thus creating a larger conceptual gap between the Mempa analysis and parole release proceedings.

However, the nature of judicial sentencing and that of parole release proceedings are actually quite similar. ${ }^{173}$ Especially in a state such as California, where the tasks of sentencing, parole release, and parole revocation are performed by the same administrative body, ${ }^{174}$ the Court's distinction as to what is and what is not part of a "criminal prosecution" becoines highly questionable. Both proceedings involve discretionary judgments which determine the length of time an individual will be incarcerated. ${ }^{175}$ In addition, the danger of sentences being based on misinfornuation, an important consideration in $M e m p a,{ }^{176}$ is equally great in parole release decisions. ${ }^{177}$ Finally, an unjustifiably lengthy sentence and an unjustified denial of parole have the same detrimental effect upon the inmate's chances for rehabilitation. ${ }^{178}$ Despite these similarities, however, the restrictive definition of "criminal prosecution" evidenced by Morrissey nakes Mempa an extrentely unreliable precedent for prospective parolees.

172. See 408 U.S. at 480 .

173. See authorities cited in note 165 supra.

174. See Cal. Penal Code $\S \S 3020,3040$ (West 1970). The California Code also provides that the members of the Adult Authority "determine and redetermine, after the actual commencement of imprisonment, what length of time, if any, such person shall be imprisoned." Id. $\S 1168$. The court, therefore, may not fix the term of imprisonment.

175. Often a judicial sentence determines when a prisoner may first be considered for parole through the use of a minimum sentence. In the same manner, the parole boards are given the discretion to determine when inmates will be considered and when they will be released on parole. "[V]iewed objectively, the parole release proceeding ... does seem in practical effect to be an extension of the sentencing process . . .." Menechino v. Oswald, 430 F.2d 403, 414 (2d Cir. 1970), cert. denied, 400 U.S. 1023 (1971) (Feinberg, J., dissenting). The determinations of a judge and a parole board are also similar because "decisions on both levels turn on a discretionary assessment of a multiplicity of imponderables, entailing primarily what a man is and what he may become rather than simply what he has done." Kadish, The Advocate and the ExpertCounsel in the Peno-Correctional Process, 45 MinN. L. Rev. 803, 813 (1961). In addition, the interests of an individual involved in either proceeding are the same. The claim of a defendant at sentencing is no greater than that of a prospective parolee, for "[o]ne who is legally convicted has no vested right to the determination of his sentence at less than maximum . . .." In re Schoengarth, 66 Cal. 2d 295, 300, 425 P.2d 200, 204, 57 Cal. Rptr. 600, 603-04 (1967).

176. 389 U.S. at 136-37.

177. This is especially true in light of the wide discretion and heavy time pressures experienced by parole boards. See notes $8-15 \& 21$ supra and accompanying text.

178. See notes 26-29 supra and accompany text. 


\section{The Need for a More Adequate Alternative}

The currently available alternatives to qualifying parole release hearings under the due process test cannot be viewed as sufficient. Several are of dubious validity in light of controlling precedent, and others lave not yet achieved general acceptance. At best, the procedural guarantees granted by these courts are a poor substitute for the full panoply of safeguards which are necessary to ensure fairness in parole board proceedings. ${ }^{170}$ Furthermore, even those courts which have allowed parole release hearings to qualify under the due process tests will be constrained by Morrissey to grant extremely limited procedural protection. ${ }^{180}$ For these reasons, it is evident that effective safeguards can be obtained only through legislative action.

\section{Proposals For Legislative Action}

The right to procedural protection at parole release hearings may be secured by state legislatures through the passage of either of two statutory schemes. First, a legislature can change the statutory framework which deals with parole release decisions in sucl a way that those decisions would in fact satisfy the requirements of the due process test. For example, the Model Penal Code has adopted a provision which proposes that an inmate be released on parole when he is first eligible ${ }^{181}$ unless one of the following four conditions exists:

(a) there is a substantial risk that he will not conform to the conditions of parole; or

(b) his release at that time would depreciate the seriousness of his crime or promote disrespect for the law; or

(c) his release would have a substantially adverse effect on institutional discipline; or

(d) his continued correctional treatment, medical care, or vocational or other training in the institution will substantially enhance his ca-

179. For an exhaustive presentation of such safeguards, see notes 194-250 infra and accompanying text.

180. Such a restriction on what process is due $\mathrm{m}$ parole release hearings is necessary to give some effect to the Morrissey Court's distinction between parole release and parole revocation proceedings. See notes 99-100 supra and accompanying text. All of the courts which have granted procedural protection have recognized this limitation upon their power to fashion relief. See Bradford v. Wcinstein, No. 73-1751 (4th Cir. Nov. 22, 1974); United States ex rel. Johnson v. Chairman of N.Y. State Bd. of Parole, 500 F.2d 925 (2d Cir.) vacated as moot sub nom. Regan v. Johnson, 43 U.S.L.W. 3294 (U.S. Nov. 19, 1974) (No. 74-108); Childs v. United States Bd. of Parole, No. 74-1052 (D.C. Cir. Dec. 19, 1974).

181. In most states, an inmate is first eligible for parole when he lias served his mimimum sentence. See Natronal Advisory COMM'N 589. 
pacity to lead a law-abiding life when released at a later date. ${ }^{182}$

The Code changes the emphasis of parole release statutes from what is now the parole board's authority to use its discretion to grant parole to the use of that discretion to deny parole, and thus correspondingly shifts the burden of proof from the inmate (to show why he should be released) to the institution (to show why parole should be demed). The change is sufficient to give the inmate a presently enjoyed entitlement to be released once he is ehigible for parole unless the board can show that one of the four specified conditions exists. The adoption of this proposed statute by the states should lead to the recognition by the courts of a right to procedural due process protection. ${ }^{183}$ However, under this approach the courts would be severely restricted by Morrissey as to the extent of the procedural safeguards which they could provide. The better statutory approach is for state legislatures to approve provisions for the imposition of specific procedural safeguards in parole release proceedings as is the case with the requirement of a hearing which currently appears in several state statutes. ${ }^{184}$ Obviously, this latter approach does not preclude the possibility or advisability of a state legislature adopting a statute similar to that contained in the Model Penal Code, ${ }^{185}$ but the legislative analysis should go further and determine precisely which procedural safeguards should be required in parole release hearings.

182. ALI Model Penal Code $\$ 305.9$ (1962). The presumption and four condi. tions have been approved by the National Commission on Reform of Federal Criminal Laws, which added a provision that once an inmate has served the longer of two-thirds of his sentence or five years, he should be paroled unless the board is "of the opinion that his release should be deferred because there is a high likel hood that he would engage in further criminal conduct." National CoMm'N ON REForm of Fed. CRIMINaL Laws, Final Report 300 (1971). Section 305.9 of the Model Penal Code has also been endorsed by the National Advisory Committee on Criminal Justice Standards and Goals. See National Advisory Comm'N 587.

183. The courts' analysis would be in terms of the prisoners' statutory entitlement to be released on parole unless the state demonstrates the mappropriateness of parole release in a particular case. Relevant precedent would be Wolff. See notes 76-77 supra and accompanying text. Of course, a legislature's motive in passing this statute would not be to secure for inmates an interest of entitlement that would satisfy the due process test. Instead, the rationale behind such a statute would properly be that since in the majority of cases parole release satisfies the state's interests more than continued imcarceration of an inmate, the burden should be placed upon the board to show why parole should not be granted once an inmate has served a designated part of his sentence. See generally NATIONAL ADvisoRy COMM'N 389-401.

184. See note 12 supra and accompanying text.

185. The provisions of the Model Penal Code might serve as merely part of a statutory scheme of standards and safeguards aimed at improving the operation of parole boards. See tẹt accompanying notes 193-94 infra. 


\section{What Process is Due at Parole Release Hearings?}

In order to determine precisely what procedural protections should be granted in a parole release hearing, the interests of the state and the individual must be analyzed in terms of the nature of the parole release proceeding and the particular safeguard proposed. Courts have traditionally used a balancing test to decide what procedures are required; ${ }^{186}$ ideally, a legislature considering needed statutory reform in the area of parole release hearings would use the same conceptual process. In Wolff $v$. McDonnell, the Supreme Court explained that "[c]onsideration of what procedures due process may require under any given set of circumstances must begin with a determination of the precise nature of the government function involved as well as of the private interest that has been affected by governmental action."187 The interests of the individual in parole release hearings are obvious: (1) the inmate desires to secure a favorable decision so that he may be released on parole, ${ }^{188}$ and (2) he also has a very strong interest in a fair consideration of his apphication.

The interests of the state are more coinplex. Parole is part of a correctional process directed at rehabilitating convicted offenders. ${ }^{189}$ It furthers this goal by providing a means of supervising the inmates' reintegration into the community. ${ }^{190}$ For the orderly administration of its prison system, a state has an interest in the immates' perceiving ${ }^{101}$ the parole procedure to be a fair one. ${ }^{102}$ Tangentially, a fair proceed-

186. See, e.g., Morrissey v. Brewer, 408 U.S. 471, 482 (1972); Goldberg v. Kelly, 397 U.S. 254, 262, 263 (1970); Cafeteria \& Restaurant Workers Local 473 v. McElroy, 367 U.S. 886, 895 (1961); Hannah v. Larche, 363 U.S. 420, 442 (1960); Joint AntiFascist Refugee Comm. v. McGrath, 341 U.S. 123, 163 (1951) (Frankfurter, J., concurring). Courts that have held that due process attaches to parole release proceedings have used a balancing test to determine whether certain procedures are required. See notes 101-23 supra and accompanying text.

187. 94 S. Ct. at 2977 , quoting Cafeteria \& Restaurant Workers Local 473 v. McElroy, 367 U.S. 886, 895 (1961).

188. It must be born in mind that a parolee's freedom is not complete. See note 104 supra.

189. "Retribution is no longer the dominant objective of the criminal law. Reformation and rehabilitation of offenders have become important goals of criminal jurisprudence." Wilhams v. New York, 337 U.S. 241, 248 (1949). The more modern view of the concept of rehabilitation is that it is a process of reintegrating the offender into the community. See National ADVISORY COMM'N 3.

190. See National Advisory COMM'N 390.

191. "Not only slould [a parole release hearing] be a fair determination in substance, but to the extent possible it also should be perceived by the inmate as fair." Id. 401 . See also O'Leary \& Nuffield, supra note 15, at 385.

192. See notes 25-29 supra and accompanying text. See J. MARTIN, Break Down THE WaLLS 93-94 (1954), explaining a number of prison riots in the past as reactions to 
ing should further the state's interest in building the inmate's respect for a system of law and order both within and outside the correctional institution.

Both the interests of the state and of the inmate can be satisfied with a statute defining parole release procedures. ${ }^{193}$ The essentials of such statutory reform should include: ${ }^{194}$

-A hearing for the inmate being considered for parole.

-Notice of when an inmate will be considered for parole and disclosure of records to be considered.

-Assistance of counsel.

-Establishment of criteria for judging an inmate's fitness for parole.

-Statement of reasons upon denial of parole.

- Judicial review of allegations that a parole board acted in an arbitrary inanner.

\section{Hearing}

The requirement of a hearing needs little discussion. That it is among the inost basic safeguards which must be observed ${ }^{105}$ is a fact

parole board practices. See also Vachss, Parole as Post-Conviction Relief: The Robert Lewis Decision, 9 New Eng. L. Rev. 1, 19 (1973).

193. The procedures suggested in this Comment would be merely one element in the complete reform of a state's parole system. The parole release hearing is one part of a larger parole program which is, in turn, an integral part of the corrections and criminal justice systems. To effect reform in the parole release area, changes in judicial sentencing (e.g., the elimination of minimum sentences) and in the organizational structure of correctional agencies (e.g., consolidating parole boards into a centralized authority) are proposed. See generally NATIONAL ADVISORY COMM'N 389-404.

194. For purposes of comparison, it is useful to bear in mind the procedural safeguards that are now required in parole revocation hearings after Morrissey v. Brewer, 408 U.S. 471,489 (1972):

(a) written notice of the claimed violations of parole; (b) disclosure to the parolee of evidence against him; (c) opportunity to be heard in person and to present witnesses and documentary evidence; (d) the right to confront and cross-examine adverse witnesses (unless the hearing officer specifically finds good cause for not allowing confrontation); (e) a "neutral and detached" hearing body such as a traditional parole board, members of which need not be judicial officers or lawyers; and (f) a written statement by the factfinders as to the evidence relied on and reasons for revoking parole.

For a recent agency attempt to provide a comprehensive set of procedures and policy guidelines, see 39 Fed. Reg. 20,028 et seq. (1974). The exhaustive paroling policy guidelines, see id. at 20,030-34, became effective nationwide on June 5, 1974. The other provisions were initially applied only in the Board's Northeast Region. See id. at 20,028.

195. The Supreme Court has stated that although

many controversies have raged about the cryptic and abstract words of the due process clause, ... there can be no doubt that at a minimum they require that deprivation of life, liberty or property by adjudication be preceded by notice 
recognized by almost all parole boards. Most boards grant hearings as a matter of practice or pursuant to statutory provisions. ${ }^{196}$

\section{Notice and Disclosure}

At a minimum, due process requires "notice and an opportunity to be heard ... 'granted at a meaningful time and in a meaningful manner" "197 before a person may be deprived of an interest protected by due process. Accordingly, it would seem that fairness would dictate the same statutory requirements. There is general agreement that a parole board should inform an inmate of any future hearing at which he will be considered for parole. However, the inmate should also be entitled to know the material upon which the board will make its decision and the sources of such information. ${ }^{188}$ Only through such disclosure will the inmate be able to brimg to the board's attention any pertinent matters which may be missing froin its file. ${ }^{199}$ Disclosure is also necessary to give the inmate a meaningful opportunity to rebut allegations or conclusions contamed in the board's materials. Increasing the sources of information upon which the board will draw in making its decisions will lead to better-informed and therefore fairer considerations of parole applications. ${ }^{200}$ The opposing governmental interest is the state's concern in mamtaining order in the correctional institution. Parole boards fear, for example, that disclosure of an inmate's accusers may lead to retaliation by the inmate agamst his accusers. In addition, informing an inmate of the contents of his psychological report may hinder his rehabilitation. ${ }^{201}$ However, there is little empirical evidence as to the latter concern, ${ }^{202}$ and as to the former, there is evidence indicating that such concern for security in

and opportunity for hearing appropriate to the nature of the case. Mullane v. Central Hanover Bank \& Trust Co., 339 U.S. 306, 313 (1950); accord, Boddie v. Connecticut, 401 U.S. 371, 377-78 (1971).

196. See notes 12-13 supra and accompanying text.

197. Fuentes v. Shevin, 407 U.S. 67, 80 (1972), quoting Armstrong v. Manzo, 380 U.S. 545,552 (1965).

198. Notice should be "reasonably calculated, under all circumstances, to apprise interested parties of the pendency of the action and afford them an opportunity to present their objections." Mullane v. Central Hanover Bank \& Trust Co., 339 U.S. 306, 314 (1950) (emphasis added).

199. See Natronal Advisory COMM'N 403.

200. Currently the information available to the parole board is prepared by institutional staff who have had little contact with the inmate. Id. at 401. The inmate himself, when apprised of the contents of his record which has been prepared without his aid, serves as a useful check on the information presented to the parole decisionmakers. Id. at 403.

201. See Parsons-Lewis 1550.

202. See NATIONAL ADVISORY COMM'N 403. 
these situations is unwarranted. ${ }^{203}$ In balancing these interests, the Corrections Task Force and the National Advisory Committee on Corrections have recommended notice which contains substantial disclosure unless there exist compelling reasons for nondisclosure of particular information. ${ }^{204}$

To increase the available information upon which the board's determination will be based, the inmate should be given the opportunity to rebut any information contained in his file by presenting evidence or calling witnesses if necessary. ${ }^{205}$ Undoubtedly this will lengthen proceedings, but the administrative burden is outweighed by the prospective gain in fairness to the inmate. To avoid arbitrary parole decisions, parole boards inust recognize that some of their information sources inay be maccurate or biased. Granting the inmate the opportunity to present evidence will also give the board some further insight into the prisoner and the advisability of release. Finally, the inmate's participation in the parole release hearing will favorably affect his view of the fairness of the decision, even if parole is denied, and his commitunent to parole conditions if he is released..$^{206}$

\section{Right to Counsel}

In Mempa v. Rhay, ${ }^{207}$ the assistance of counsel was seen necessary in a combined probation revocation and deferred sentencing hearing. The Court felt counsel would aid in "marshalling the facts, introducing evidence of mitigating circumstances and in general aiding and assisting the defendant to present his case as to sentence."208

203. A similar concern for secrecy was raised in Wolff in connection with the right to present. and cross-examine witnesses in prison disciplinary proceedings. $94 \mathrm{~S}$. Ct. at 2979-80. However, the dissent in Wolff pointed to studies which had established that such procedures had no noticeable affect on prison security and commented that the Court's refusal to enforce fundamental rights because of a concern for secrecy was "permitting the tail to wag the constitntional dog" as secrecy was involved in only a tiny fraction of disciplinary cases. Id. at 2990 (Marshall, J., dissenting).

204. National Advisory COMM'N 403; TASK FORCE REPORT 86. Similar reasoning led the Court in Morrissey v. Brewer to require the presence of adverse witnesses at a parole revocation hearing at the parolee's request, so long as this safeguard would not endanger the witness. 408 U.S. at 487 . However, the Court has refused to extend such a requirement to allow a person to call and cross-examine witnesses as to nuatters in the pre-sentence report relied upon by a sentencing judge, see Willianıs v. New York, 337 U.S. 241 (1949), although the Conrt has realized the unconstitutionality of sentences based upon material errors in the record. See, e.g., United States v. Tucker, 404 U.S. 443 (1972); Townsend v. Burke, 334 U.S. 736 (1948).

205. See generally Chanibers v. Mississippi, 410 U.S. 284, 302 (1973) (right to present witnesses is fundamental to due process).

206. See NATIONAL Advisory COMM'N 401.

207. 389 U.S. 128 (1967).

208. Id. at 135 . 
Though the Second Circuit in Menechino v. Oswald ${ }^{20 n}$ reasoned that the Mempa analysis should not be applied to parole release decisions, ${ }^{210}$ the actual similarity between sentencing and parole release procedures suggests the contrary conclusion. ${ }^{211}$ In Menechino, the court found that parole release proceedings were not adversarial, ${ }^{212}$ but there are strong indications that this is not true. Although there may be an ostensible identity of interest between the board and inmate, the significance of that fact has been diminished by the courts in comparable situations. ${ }^{213}$ Furthermore, though the board may be seeking to rehabilitate the inmate, the inere form of the proceeding with the inmate appearing before the parole board which will decide his fate inevitably creates an image of an adversarial process in the inmate's mind. ${ }^{214}$

In Menechino, the Second Circuit also stated that assistance of counsel is unnecessary because parole boards do not resolve issues of fact. ${ }^{215}$ Yet factual determinations are sometimes critical in a board's decision. ${ }^{216}$ Although there may be little factual adjudication in the traditional sense of the term, certain factors are involved which must be analyzed as in a sentencing hearing (where counsel is allowed) to determine what action will best serve the interests of the inmate. ${ }^{.17}$

209. 430 F.2d 403 (2d Cir. 1970), cert. denied, 400 U.S. 1023 (1971).

210. Id. at 407.

211. See notes 173-78 supra and accompanying text.

212. $430 \mathrm{~F} .2 \mathrm{~d}$ at 407 . Instead, the court in Menechino said that the board had an identity of interest with the prisoner seeking parole. Id. See also Hyser v. Reed, 318 F.2d 225, 237 (D.C. Cir.), cert. denied, 375 U.S. 957 (1963), where the court stated:

The Bureau of Prisons and the Parole Board operate from the basic premise that prisoners placed in their custody are to be rehabilitated and restored to useful lives as soon as in the Board's judginent that transition can be safely made. ... Thus there is a genuine identity of interest if not purpose in the prisoner's desire to be released and the Board's policy to grant release as soon as possible.

213. See In re Gault, 387 U.S. 1, 27-29 (1967), where the argument of an identity of interest between a court and a juvenile was rejected. The Court held that due process requirements depend upon the reality of the system, which in that case involved adversary interests in fact and the possibility of a substantial imjury flowing from the proceeding. It should also be noted that counsel was required in Mempa v. Rhay, 389 U.S. 128 (1967), although supposedly there is an identity of interest between the defendant and sentencing judge.

214. See 23 EMORY L.J. 597, 612 (1974).

215. 430 F.2d at $407-08$.

216. Cf. United States ex rel. Gallagher v. Daggett, 326 F. Supp. 387, 390 (D. Minn. 1971) (court recommendation that parole authorities consider that information supplied by prison officials might be one-sided).

217. Such adjudicatory facts to be considered by the board include the inmate's prior criminal record, the inmate's personal situation at the time the crime was committed, and the course of the inmate's conduct in prison. See Kadish, supra note 175, at 829; The Parole System 362. 
Such factors are contained largely in the prisoner's record prepared without the inmate's aid. ${ }^{218}$ The hearing inay be the inmate's single chance to present his view of his particular situation; the importance of the hearing should mandate that counsel be present to aid in the presentation of that view. ${ }^{219}$ Therefore, the presence of counsel at a hearing might guarantee that the board's determination was a considered one. ${ }^{220}$ In addition, counsel may be necessary to preserve the inmate's right of appeal upon a denial of parole which appears to have been nuade arbitrarily or contrary to parole regulations or statutes. ${ }^{21}$

Set against these considerations are the possible administrative burdens that the state might experience if an inmate were given the assistance of counsel at every parole release proceeding. For example, there is the possibility that hearings would consume more time due to counsel's technical objections and lengthy presentations. Yet, as in the courts, parole boards would still retain the power to set rules governing the extent and manner in which counsel could participate. ${ }^{222}$ The cost of providing counsel to indigents is also an important consideration. However, to the extent that counsel succeeded in procuring parole for an inmate, the correctional institution's costs would actually be reduced. ${ }^{223}$ In addition, alternatives have been suggested which would neet the various administrative burdens including cost of providing for counsel at parole release proceedings. ${ }^{224}$ Balancing these interests, the National Advisory Cominission has recoinmended that inmates have legal assistance at parole release proceedings. ${ }^{225}$

218. See note 23 supra and accompanying text. Often, the inmate cannot even see his file. See TASK Force REPort 87.

219. Factors such as the prisoner's lack of education and tension due to the importance of the decision may cause the inmate to experience difficulty in clearly presenting his side of the story. Counsel would protect the prisoner as well as the board against action based on this information. See NATIONAL ADvisory COMM'N 403. See also Kadish, supra note 175, at 829-30; The Parole System 362.

220. See NATIONAL AdVISORY COMM'N 403; Kadish, supra note 175, at 832.

221. See Jacob \& Sharma, Justice After Trial: Prisoner's Need for Legal Services in the Criminal-Correctional Process, 18 U. KAN. L. REv. 493, 535 (1970).

222. See Parsons-Lewis 1552 . In 1972 , at least nineteen jurisdictions were permitting assistance of counsel in either the preparation for a parole release hearing or in the hearing itself. Id.

223. See note 226 infra and accompanying text.

224. One solution might be to permit law students or other legally trained individuals to aid the inmate. See also Menechino v. Oswald, 430 F.2d 403, 416 (1970), cert. denied, 400 U.S. 1023 (1971) (Feinberg, J., dissenting) (counsel should be allowed to represent prisoner in each subsequent parole release hearing after an initial denial); ALI MODEL PENAL CODE $\$ 305.7$ (1962) (consultation with counsel before hearing in lieu of representation at hearing); Tappan, The Role of Counsel in Parole Matters, 3 PRAC. LAW. 21, 26-27 (Feb. 1967) (attorney may submit written arguments on behalf of applicants).

225. NATIONAI AdVISORY COMm’n $403 \& 423$. 


\section{Parole Criteria}

It is to the state's advantage to parole an inmate as soon as he is "ready" to be paroled and no later. From an administrative viewpoint, parole is far more economical than imcarceration. ${ }^{226}$ Even more important is the evidence that prolonged incarceration increases the likelihood of recidivism. ${ }^{227}$ Therefore, those individuals whose release on parole would neither decrease their prospects of successful rehabilitation nor create a risk to society should be released from prison as soon as possible. ${ }^{228}$ In view of the fact that timely parole release of an individual is actually beneficial to the state, there is little justification for making an inmate bear the burden of showing why he should be released. Rather, the board should bear the burden of establishing why parole should be denied. ${ }^{229}$

In reaching this determination the board should establish specific, binding criteria. ${ }^{230}$ The criteria should serve the purpose of achieving consistency among parole release decisions and should mclude such factors as (a) the inmate's parole plans; (b) the nature of his ties to the coinmunity; (c) his intelligence, training, and previous employment record; (d) his willingness and ability to accept responsibility; (e) any previous history of use of narcotics or excessive use of alcohol; (f) his prior criminal record; (g) his conduct during any previous probation or parole; (h) his conduct in prison, especially the degree to which he has participated in rehabilitative programs; (i) his attitude toward authority and the law; and (j) other factors reflecting upon the inmate's physical and psychological makeup which would have a serious effect upon the inmate's ability to conform to the law. ${ }^{231}$ Such cri-

226. A 1966 survey showed state correctional institutions expended an average of $\$ 1,912.60$ each year per inmate. During the same period parole supervision cost $\$ 323$ per inmate, or one-sixth as inuch. The Parole System 294 n.76.

227. Bixby, A New Role for Federal Parole Boards, 34 Fed. Probatnon 24 (June 1970). A survey of American parole practices concluded: "The problem of parole selection becomes one of retaining the inınate until he has reached his [rehabilitative] peak and then releasing him; incarceration after this point is regarded as detrimental to adjustment on parole." Dawson, supra note 14, at 257.

228. The National Advisory Commission has recommended that some inmates be released on parole before the expiration of their ininimum sentence (the point of initial eligibility for parole in most states) and that minimum sentences be eliminated. NATIONAL ADVISORY COMM'N 393.

229. Such is the effect intended in section 305.9 of the Model Penal Code. See note 182 supra and accompanying text.

230. See United States ex rel. Johnson v. Chairman of N.Y. State Bd. of Parole, 500 F.2d 925, 929-30 (2d Cir.), vacated as moot sub nom. Regan v. Johnson, 43 U.S.L.W. 3294 (U.S. Nov. 19, 1974) (No. 74108); Vachss, supra note 192, at 38.

231. See United States ex rel. Johnson v. Chairman of N.Y. State Bd. of Parole, 500 F. $2 \mathrm{~d}$ 925, 930 (2d Cir.), vacated as moot sub nom. Regan v. Johnson, 43 U.S.L.W. 
teria should be weighted and periodically revised in accordance with their apparent effectiveness in predicting "good risks" for parole..$^{232}$ Appropriate use should be made of the numerous special studies which have been conducted throughout the country in order to determine the validity of various parole criteria. ${ }^{233}$ In turn, the findings of parole boards should be made available to specialists, as these studies provide a valuable tool for evaluation and reform of parole systems. ${ }^{234}$

\section{Statement of Reasons}

Courts that have granted relief to inmates seeking some procedural protection have held that a statement of reasons must be given by the parole board upon denial of parole. The imposition of such a requirement would have a substantial inipact upon the preservation of all the interests involved. First, a statement of reasons would facilitate judicial review of parole board decisions to determine whether a parole board decision has been made arbitrarily or through the use of inappropriate criteria. ${ }^{235}$ Without a statement of reasons, a court cannot determine the grounds upon which parole was denied, a fact which renders useless its power of judicial review.

A second justification for a required statement of reasons is that it “'promotes thought by the decider,' and 'compels him to cover the relevant points' and 'eschew the irrelevancies," "'236 as it "insures a respon-

3294 (U.S. Nov. 19, 1974) (No. 74-108); Cal. Penal Code $\$ 5068$ (West 1970); Kan. Stat. ANN. § 62-2245 (1964); ALI Model Penal Code $\$ 305.9(2)$ (1962); Dawson, supra note 14, at 248-95.

232. See United States ex rel. Johnson v. Chairman of N.Y. State Bd. of Parole, 500 F.2d 925, 930 (2d Cir.), vacated as moot sub nom. Regan v. Johnson, 43 U.S.L.W. 3294 (U.S. Nov. 19, 1974) (No. 74-108); Vachss, supra note 192, at 40.

233. See, e.g.., L. Ohlin, Selection for Parole: A Manual of Parole Prediction (1951); Burchess, Factors Determining Success or Failure on Parole, in THE Working of the Indeterminate-Sentencing LaW and the Parole System IN Illinois 205 (A. Bruce, A. Harno, E. Burgess \& J. Landesco eds. 1928); Glaser, A Reconsideration of Some Parole Prediction Factors, 19 AM. Sociology Rev. 335 (1954); Kirby, Parole Prediction Using Multiple Correlation, 59 AM. J. Sociology 539 (1954); Vachss, supra note 192.

234. Some state correctional systeuns are already making use of such studies. See Burchess, supra note 233.

235. See United States $e x$ rel. Johnson v. Chairman of N.Y. State Bd. of Parole, 500 F.2d 925, 929 (2d Cir.), vacated as moot sub nom. Regan v. Johnson, 43 U.S.L.W. 3294 (U.S. Nov. 19, 1974) (No. 74-108). See generally Dawson, supra note 14; Comment, Curbing Abuse in the Decision to Grant or Deny Parole, 8 Harv. Civ. RIGHTS-Crv. LiB. L. REv, 419 (1973).

236. United States ex rel. Johnson v. Chairman of N.Y. State Bd. of Parole, 500 F.2d 925, 931 (2d Cir.), vacated as moot sub nom. Regan v. Johnson, 43 U.S.L.W. 3294 (U.S. Nov. 19, 1974) (No. 74-108). 
sible and just determination by the agency."237 Therefore, in individual cases, by naking visible the board's justifications for its decision, a statement of reasons would promote thoughtful decision-making. More generally, such a requireinent would aid in developing a body of rules, principles, criteria, and specific precedents which would stimulate greater consistency in parole determinations. ${ }^{238} \mathrm{~A}$ inore general understanding of how parole boards reach their decisions would also aid trained experts in their efforts to understand and critically review the parole system as a whole. ${ }^{239}$

Finally, a statement of reasons would promote rehabilitation of the inmate by relieving his frustration as to how to improve his chances for parole release. When an inmate is given no reasons for the denial of his parole, he might suspect that the determination was based upon soine damaging information that he could have refuted. He does not know in what ways he can change his behavior so as to impress the board favorably at his next interview. ${ }^{240}$ In considering the effect of a statenient of reasons upon an inmate's rehabilitation, the Second Circuit concluded that "fundamental fairness would seein to dictate that rather than subject a prisoner who is denied parole to the inhumamity of ignorance the state should as a matter of minimun due process provide him with the reasons." ${ }^{241}$

While many interests would be satisfied by requiring a statement of reasons, the consequential burden put upon the state would not be great. $^{242}$ There is also the possibility that if each inmate's case was

237. Id.; United States ex rel. Harrison v. Pace, 357 F. Supp. 354, 357 (E.D. Pa. 1973).

238. United States $e x$ rel. Johuson v. Chairman of N.Y. State Bd. of Parole. 500 F.2d 925, 933 (2d Cir.), vacated as moot sub nom. Regan v. Johnson, 43 U.S.L.W. 3294 (U.S. Nov. 19, 1974) (No. 74-108); see K. Davis, supra note 26, at 106-07; National ADVISORY COMM'N 402.

239. See United States ex rel. Johnson v. Chairman of N.Y. State Bd. of Parole, 500 F.2d 925, 933 (2d Cir.), vacated as moot sub nom. Regan v. Johnson, 43 U.S.L.W. 3294 (U.S. Nov. 19, 1974) (No. 74-108); Comment, supra note 235, at 440-44.

240. See note 19 supra and accompanying text.' See King v. United States, 492 F.2A 1337, 1340 n.11 (7th Cir. 1974); United States ex rel. Harrison v. Pace, 357 F. Supp. 354 (E.D. Pa. 1973).

241. United States ex rel. Johnson v. Chairman of N.Y. State Bd. of Parole, 500 F.2d 925, 933 (2d Cir.), vacated as moot sub nom. Regan v. Johnson, 43 U.S.L.W. 3294 (U.S. Nov. 19, 1974) (No. 74-108); see United States ex rel. Harrison v. Pace, 357 F. Supp. 354, 357 (E.D. Pa. 1973); Monks v. New Jersey State Parole Bd., 58 N.J. 238, 246-47, 277 A.2d 193, 198 (1971); NATIONAL ADVISORY COMM'N 402; TASK ForCE REPORT 86.

242. Iu fact, the state in United States ex rel. Johnson v. Chairman of N.Y. State Bd. of Parole, 500 F.2d 925, 933 (2d Cir.) vacated as moot sub nom. Regan v. Johnson, 43 U.S.L.W. 3294 (U.S. Nov. 19, 1974) (No. 74-108), did not even argue that such a burden would be a factor. The lightness of the burden is evidenced by the fact that in 
more carefully considered, more prisoners would be released on parole. The result would be a great savings in costs for the correctional system, ${ }^{243}$ which would free funds to ease parole boards' workloads or provide greater legal assistance to prisoners. ${ }^{24}$ The National Advisory Commission has recommended that immates be informed personally by the board of the reasons for a demial of parole and that the board make a written statement of reasons documenting their decision. ${ }^{245}$

\section{Judicial Review}

While the decision of whether or not to grant parole is inescapably a discretionary one, and while courts should not lightly set aside the determinations of an experienced parole board, courts should have the authority to consider a claim that such a decision was made arbitrarily or that appropriate procedural safeguards were not observed. ${ }^{246}$ Access to a source of review outside the correctional system is essential to protect the inmate from arbitrary action on the part of the parole board. ${ }^{247}$ The emphasis of the courts should be placed upon the adequacy of the parole release proceeding; ${ }^{248}$ effective judicial review would

1973 more than one-half of the states were either recording their reasons for their decisions or informing the inmate directly of their justifications.

243. See note 226 supra.

244. See generally TASK FORCE REPORT 86.

245. National ADVISORX COMM'N 422.

246. Such a right has been acknowledged by some courts. See United States ex rel. Harrison v. Pace, 357 F. Supp. 354, 356 (E.D. Pa. 1973), where the court said that it had the power of judicial review where the Board had acted in an arbitrary and capricious inanner, where it had abused its discretion, or where the petitioner had been denied a constitutional right. In United States ex rel. Johnson v. Chairman of N.Y. State Bd. of Parole, 500 F.2d 925, 929-30 (2d Cir.), vacated as moot sub nom. Regan v. Johnson, 43 U.S.L.W. 3294 (U.S. Nov. 19, 1974) (No 74-108), the court stated that

[t]he broad powers vested by statute in the Board do not reheve it from the duty of observing meaningful criteria .... .

... [J]udicial review should be available where the Board has arrogated to itself decisions properly made only by the legislature, when the Board's decision in a case is inconsistent with statutory directives, when improper criteria are used, or when its decision has no basis in the prisoner's file.

247. See United States ex rel. Johnson v. Chairman of N.Y. State Bd. of Parole, 500 F.2d 925, 929-31 (2d Cir.), vacated as moot sub nom. Regan v. Johnson, 43 U.S.L.W. 3294 (U.S. Nov. 19, 1974) (No. 74-108). The Second Circuit einphasized the importance of a judicial responsibility to see that the parole boards do not engage in policy decisions which are beyond their discretionary authority: "Without interfering with the Board's ability to exercise its discretion in future cases, it is our duty to determine whether the criteria used by the Board are consistent with the legislative purpose as expressed in the statute, and whether they are followed in practice." Id. at 931 (citation oinitied).

248: The President's Task Force on Corrections emphasized that such judicial review would not inmerse the courts in the discretionary affairs of the parole boards: "Experience with appellate review of sentencing decisions indicates that even if courts 
encourage parole boards to establish and abide by criteria and procedures that would dimish the likelihood of successful challenges. ${ }^{249}$ The resulting practice would be fairer in substance and would appear fairer to the inmate. ${ }^{250}$

\section{CoNCLUSION}

In the current era of prison unrest and public concern about the correctional systein, it is appropriate that courts have shown an increased willingness to protect the rights of inmates. Constitutional guarantees have been extended into virtually every phase of prison life as the traditional excuses for judicial noninterference have been exposed and abandoned. However, parole release hearings, in which the exercise of state power has the greatest effect upon an ordinary inmate's future, have been shielded to a great extent from these developments. The major obstacle which permits this uncontrolled official discretion is the rigid "present enjoyment" requirement of the due process test which has been erected by the Supreme Court in its recent decisions. Until this test is discarded or limited to "property" interests, aggrieved prisoners must look elsewhere even for minimal relief. Moreover, even if parole release hearings should be held subject to the due process clause, the extent of procedural protection which would result is clearly imadequate to protect the prisoners' interest in a fair decision.

It is the legislatures which must eliminate the anomaly created by this judicial failure. Limited relief can be achieved by granting prisoners a statutory entitleinent in prospective parole; however, truly effective protection will result only from the direct imposition of specific procedural safeguards. The "parole release exemption" from the recent expansion of prisoners' rights should be swiftly destroyed. The costs of inaction are too high, and the justifications of perpetuating today's deplorable system are too few.

assumed the power to review parole decisions on the merits, reversals on the ground of abuse of discretion would be rare." TASK FORCE REPORT 86.

249. See Parsons-Lewis 1553.

250. See note 191 supra. The National Advisory Commission also recommends that parole authorities "establish self-regulation systems, including internal appeal procedures" in order to "develop correctional policy consistent with correctional needs and judicial standards." National ADvisory COMM'N 397-98. An inmate would be interviewed by a hearing examimer who would make an initial decision as to parole release. That decision would become final unless appealed to the full board. On appeal, the board could overturn the discretionary decision of the hearing examiner based not upon a hearing de novo but on briefs and arguments. A dissatisfied party could appeal the decision of the board to the court which would decide whether, upon the evidence, the agency's decision was authorized or erroneous as a matter of law. Id. at 403-04. 